Chapman University

Chapman University Digital Commons

War and Society (MA) Theses

Dissertations and Theses

Summer 8-2020

\title{
The Myth of the Green Berets: How One Group of Soldiers Helped Sell a Nation on the Virtue of War
}

\author{
Rebekah Moore \\ Chapman University, rebmoore@chapman.edu
}

Follow this and additional works at: https://digitalcommons.chapman.edu/war_and_society_theses

Part of the United States History Commons

\section{Recommended Citation}

Moore, Rebekah W. "The Myth of the Green Berets: How One Group of Soldiers Helped Sell a Nation on the Virtue of War." Master's thesis, Chapman University, 2020. https://doi.org/ 10.36837/chapman.000199

This Thesis is brought to you for free and open access by the Dissertations and Theses at Chapman University Digital Commons. It has been accepted for inclusion in War and Society (MA) Theses by an authorized administrator of Chapman University Digital Commons. For more information, please contact laughtin@chapman.edu. 


\title{
The Myth of the Green Berets:
}

\section{How One Group of Soldiers Helped Sell a Nation on the Virtue of War}

\author{
A Thesis by \\ Rebekah W. Moore \\ Chapman University \\ Orange, CA \\ Master of Arts in War and Society \\ August 2020 \\ Committee in charge: \\ Gregory A. Daddis, Ph.D., Chair \\ Jennifer D. Keene, Ph.D. \\ Robert A. Slayton, Ph.D.
}

Wilkinson College of Arts, Humanities, and Social Sciences

Submitted in partial fulfillment of the requirements for the degree of 
The thesis of Rebekah W. Moore is approved.

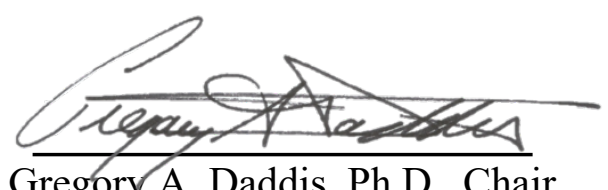

Gregory A. Daddis, Ph.D., Chair

Yennifer OD. Teene

Jennifer D. Keene, Ph.D.

Rofert A. Slayton

Robert A. Slayton, Ph.D.

August 2020 


\section{The Myth of the Green Berets:}

How One Group of Soldiers Helped Sell a Nation on the Virtue of War

Copyright (C) 2020

by Rebekah W. Moore 


\section{ACKNOWLEDGEMENTS}

This thesis would not have been possible without the encouragement, and the outlining wizardry, of Dr. Gregory Daddis. He kept me on track and motivated even during a pandemic and was unreserved with his time and support.

The War and Society program has a brilliant assemblage of professors and students. I am fortunate to have learned from and studied with them this past year. Mateo Jarquin, Michael Wood, Stephanie Takaragawa, Alexander Bay, and Robert Slayton all provided instruction and insight that helped make my time at Chapman manageable and memorable. A special thanks to Dean Jennifer Keene, who introduced me to the Center for American War Letters and the amazing correspondence therein.

Fellow scholar and Foreign Service Officer Vanessa Zenji kept me sane through it all. Her ability to juggle work, school, and family was both inspiring and dumbfounding.

The generosity of the Mark Chapin Johnson Foundation enabled my studies. Their continued support of interdisciplinary scholars has helped make the War and Society program a noteworthy one.

Finally, I would like to thank my parents, who have always encouraged me to follow my heart. Their support is unwavering, even when my path is unconventional. A special thanks to my brother Jacob, whose unparalleled pyrotechnic and zodiac-warrior skills inspired this study.

This work is dedicated to Special Forces medic Thomas Hepburn Perry, who was killed in battle at Ngok Tavak on May 10, 1968. He was everything the Green Berets aspire to be. 


\begin{abstract}
The Myth of the Green Berets:

How One Group of Soldiers Helped Sell a Nation on the Virtue of War

by Rebekah W. Moore
\end{abstract}

While various types of American military units fought in the Vietnam War, a disproportionate amount of media attention concentrated on one group: the Special Forces. More commonly known as the Green Berets, these "elite" soldiers were lauded in the Vietnam era for their foreign language skills, martial prowess, and mastery of unconventional warfare. Their ability to live and work with local populations made them the favored-and famed-warrior diplomats of President John F. Kennedy's New Frontier. During the 1960s, the Green Berets were featured in best-selling novels, a chart-topping song, comic book titles, action figures, bubblegum cards, and a successful film. It was not only the American public who embraced these elite soldiers, however. Military officials, government policy planners, and the media all believed, to varying degrees, in the mythic abilities of the Special Forces. Deployed to Vietnam with the expectation that they could solve political, social, and economic problems, they were ultimately were unable to fulfill their mission. Even in defeat, however, the luster of the Green Berets remained virtually undimmed and America could reimagine victory in the jungles of Southeast Asia through John Rambo in the 1980s. An examination of these myths reveals the deep, and dangerous, cultural roots that undergird notions of democratic progress, American exceptionalism, and military interventionism, ideas that have found new life in the Global War on Terror. 


\section{TABLE OF CONTENTS}

\section{Page}

ACKNOWLEDGMENTS ................................................... IV

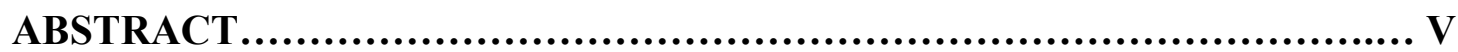

LIST OF ABBREVIATIONS................................................... VII

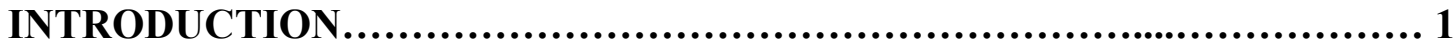

1 THE ORIGINS OF SPECIAL FORCES AND COUNTERINSURGENCY WARFARE 9

2 THE MYTH OF THE GREEN BERETS, 1961-1964............................ 22

3 THE ENSHRINEMENT OF THE MYTH, 1965-1968........................... 34

4 GREEN BERETS IN VIETNAM, 1965-1970................................. 56

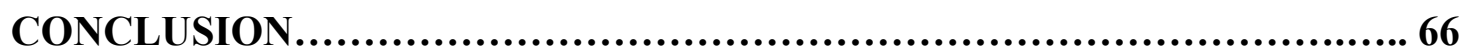

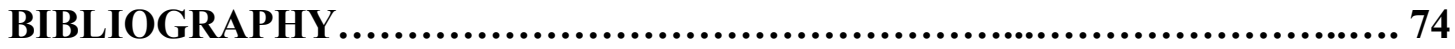




\section{LIST OF ABBREVIATIONS}

$\begin{array}{ll}\text { Abbreviation } & \text { Meaning } \\ \text { CIA } & \text { Central Intelligence Agency } \\ \text { CIDG } & \text { Civilian Irregular Defense Group } \\ \text { MACV } & \text { Military Assistance Command, Vietnam } \\ \text { NSAM } & \text { National Security Action Memorandum } \\ \text { OCS } & \text { Officer Candidate School } \\ \text { OSS } & \text { Office of Strategic Services }\end{array}$




\section{Introduction}

There are many popular culture icons of the 1960s — the Beatles, Andy Griffith, Batman, Marilyn Monroe, and Barbie to name but a few. But one of the earliest and most enduring was that of the Green Beret. Popularized during the presidency of John F. Kennedy, these U.S. Army soldiers were lionized in comic books, novels, hit singles, movies, and bubble-gum machine toys. But for all the popular culture artifacts and publicity, few military groups are as misunderstood as the Special Forces. ${ }^{1}$ Are they the pachyderm-transporting humanitarians of Operation Dumbo Drop or the avenging master of nature's weapons from Rambo? This conflict about the "true" mission of Special Forces is emblematic of larger, societal debates over the nature of American military interventionism and those that fight on their nation's behalf. Are they diplomats in dungarees, bringing modernization in their wake or highly trained killers, eliminating threats to our home front and way of life?

The popular myth of the Green Berets, first developed during the Vietnam era, was never a static concept. Rather, it reflected differing ideas of American warfare and was broad enough to reflect back onto the viewer his or her own ideas of American exceptionalism-ideas that changed over time. In Kennedy's New Frontier, these men represented the vanguard of the fight against communism. Yet they were never simply well-trained soldiers. Their martial prowess was presented, by Kennedy himself, primarily as the means by which they delivered social and economic progress to "people in the huts and villages of half the globe struggling to break the

\footnotetext{
${ }^{1}$ While these soldiers are officially known as "Special Forces," popular culture and much of the scholarship use the term "Green Berets." Members of the Special Forces community, however, rarely refer to themselves as Green Berets.
} 
bonds of mass misery." "2 This image of the Green Berets as social warriors was a common feature in early 1960s media, with numerous articles praising their multi-lingual, culturally attuned abilities. However, these abilities were often overshadowed by language and images that were more evocative of their lethality than their humanitarianism, a trend epitomized by the publication of The Green Berets, a 1965 bestseller from Robin Moore which focused almost exclusively on the male-fantasy heroics of these soldiers in Southeast Asia. Regardless of which image more accurately portrayed the abilities of the Special Forces, they enabled both policy makers and the American public to believe in the invincibility of our military endeavors, a trend that continues to this day. For while counterinsurgency may have "withered after an initial vogue," as scholars in the 1970s noted, the Global War of Terror has returned it to a position of prominence. $^{3}$

The readiness with which the myth of the Green Berets was accepted by government officials and the wider public can be explained by its linkage to older, deeply rooted myths: the myths of the American frontier and the frontier hero. Historian Richard Slotkin defines myths as “stories drawn from a society's history, which have acquired through persistent usage the power of symbolizing that society's ideology and dramatizing its moral consciousness, with all of the complexities and contradictions that consciousness may contain."4 Though commonly thought of as a binary construct — the enlightened settler versus "savage" native people — the frontier myth

\footnotetext{
${ }^{2}$ John F. Kennedy, Inaugural Address, January 20, 1961; transcript from John F. Kennedy Presidential Library and Museum.

${ }^{3}$ Richard K. Betts, Soldiers, Statesmen, and Cold War Crises (Cambridge: Harvard University Press, 1977), 128. For examples of the continued fascination with Special Forces, see Harm Venhuizen, "How the Green Berets Got Their Name," Army Times, July 14, 2020, https://www.armytimes.com/off-duty/2020/07/14/how-the-green-beretsgot-their-name/; Doug Stanton, Horse Soldiers: The Extraordinary Story of a Band of U.S. Soldiers Who Rode to Victory in Afghanistan (New York: Scribner, 2010); Eric Blehm, The Only Thing Worth Dying For: How Eleven Green Berets Fought for a New Afghanistan (New York: Harper Perennial, 2011); and Joe Kubert, Dong Xoai, Vietnam 1965 (DC Comics, 2010).

${ }^{4}$ Richard Slotkin, "Gunfighters and Green Berets: 'The Magnificent Seven' and the Myth of Counterinsurgency," Radical History Review, no. 44 (Spring 1989): 68.
} 
includes an additional component: separation from civilization. ${ }^{5}$ While initially this signified a departure, and a distinction, from ancient and outdated European values and colonization efforts, it also later represented leaving behind American cities and outposts to enter the purifying wilderness of the frontier, where settlers confronted and overcame both nature's primitiveness and the savagery which ruled it. Mastery of these primal forces entitled the settlers to their noble enterprise of western expansion. ${ }^{6}$

As the myth was inherently one of violent suppression, both of the wilderness and of the people who had originally inhabited it, the frontier hero became an integral part of what was fast becoming a national myth. Also referred to as the "monomythic superhero" or simply the "gunfighter," these men came to the aid of settlers threatened by unruly outlaws or savage Indians. ${ }^{7}$ And while their exact values and skills changed over time, reflecting larger societal shifts, the hero was consistently an outsider with legendary weapons' prowess, particularly of native weaponry, whose purity of motivation made all but inevitable his ultimate victory and the deliverance of those on whose behalf he fought. ${ }^{8}$ While the frontier hero was a master of violence, his use of it was justified by the morality of his cause; his violence was never wanton, and his restraint lifted only when absolutely necessary. ${ }^{9}$ It was onto this mythic framework that the Green Berets were to find themselves cast as the gunfighters of a new frontier.

\footnotetext{
${ }^{5}$ See Richard Slotkin, Gunfighter Nation: The Myth of the Frontier in Twentieth-Century America (Norman, OK: University of Oklahoma Press, 1998); and Jill Lepore, The Name of War: King Philip's War and the Origins of American Identity (New York: Alfred A. Knopf, 1998).

${ }^{6}$ On this topic, see Richard Slotkin, Regeneration through Violence: The Mythology of the American Frontier, 1600-1860 (Norman, OK: University of Oklahoma Press, 1973).

${ }^{7}$ Robert Jewett and John Shelton Lawrence, The American Monomyth (Garden City, NY: Anchor Press/Doubleday, 1977), 195; see Slotkin, Gunfighter Nation, for a discussion of the gunfighter; and John Hellmann, American Myth and the Legacy of Vietnam (New York: Columbia University Press, 1986) for a discussion of the frontier hero.

${ }^{8}$ For an analysis of the hero narrative in Westerns, see Matthew Carter, Myth of the Western: New Perspectives on Hollywood's Frontier Nation (Edinburgh: Edinburgh University Press, 2014). For the evolution of the frontier to include space, see Janice Hocker Rushing, "Mythic Evolution of 'The New Frontier' in Mass Mediated Rhetoric," Critical Studies in Mass Communication 3, no. 3 (September 1986): 265-296.

${ }^{9}$ See Jewett and Lawrence, The American Monomyth, 195; Carter, Myth of the Western, 37; and Hellmann, American Myth and the Legacy of Vietnam, 47.
} 
Scholars have long been fascinated by society's obsession with the Vietnam-era Green Berets. As early as 1984 they were referred to as the "soldier at the heart of the war," whose myth was representative of America's "purpose and experience" in Vietnam. ${ }^{10}$ Most studies focus on the manner in which President Kennedy manufactured and cultivated their mystique to garner support for his counterinsurgency proposals, thus facilitating American involvement in Vietnam. ${ }^{11}$ Some scholars take this a step further, arguing that President Kennedy's use of myth to support foreign policy was responsible for the magnitude of our disillusionment in defeat. ${ }^{12}$ John Hellmann examines the Green Beret as the "reincarnation of the western hero" in his larger study on myth and Vietnam, arguing that our failure in Southeast Asia called into question the very legitimacy of the frontier myth and that only through integrating the lessons of our errors can we find our way to a new national narrative. ${ }^{13}$

As this study will argue, however, the Green Beret mythology reveals more than just one president's interest in counterinsurgency or a discrete period of time during which the country marched, reinvigorated, into the landscape of the New Frontier. Rather, even through the disillusionment of the post-Vietnam years, our belief in the myth of the frontier hero and his redemptive quest was sustained and exposed by a continued belief in these soldiers. In such 1970s films as The Deer Hunter and Apocalypse Now-which one film scholar refers to as "shattering and apocalyptic" - Green Berets continued to be portrayed as either the only soldiers to emerge from the war unbroken or as the sole individuals who see through the lies to the

\footnotetext{
${ }^{10}$ Alasdair Spark, "The Soldier at the Heart of the War: The Myth of the Green Beret in the Popular Culture of the Vietnam Era," Journal of American Studies 18, no. 1 (April 1984): 30.

${ }^{11}$ See J. Justin Gustainis, "John F. Kennedy and the Green Berets: The Rhetorical Use of the Hero Myth," Communication Studies 40, no. 1 (1989): 41-53.

${ }^{12}$ See Cindy Koenig, "The Story of the Green Berets: An Account of the American Monomyth," Journal of the Northwest Communication Association 32 (Summer 2003): 59-77.

${ }^{13}$ Hellmann, American Myth and the Legacy of Vietnam, 45.
} 
madness at the heart of America's war in Vietnam. ${ }^{14}$ While popular culture of the 1980s and 1990s tended to portray them more as over-muscularized superheroes in action figures and blockbuster movies, the 2001 U.S. invasion of Afghanistan brought them squarely back to their Kennedy-era charm as the culturally savvy horse soldiers who rode to "victory" over the Taliban. The Green Berets thus play an integral role in broader myth-making that historian Andrew Bacevich argues helps sustain the "new American militarism."15 This myth is not based on one definitive frontier hero, but rather on many different versions of the American frontiersman held by disparate groups: the public, government officials, the military establishment, and individual soldiers themselves. An examination of these groups and how each was enthralled by the promise of the Green Berets reveals more important truths about how cultural assumptions influence the ways we formulate foreign policy and wage war. But the mythology does more than just reveal these beliefs, it reinforces them. Thus, we see that when the Green Beret mission in Vietnam failed to yield overwhelmingly favorable results, the soldiers were able to blame their tradition-bound leaders, the military could blame the politicians or the media, and the public could cast blame on any number of possible sources. Regardless of where the blame lies, however, it can never lie with the men who wear the green beret, for they are "us," and "our" cause is the benevolent one of freedom, democracy, and progress.

Essential to understanding the mythology and its rapid spread within popular culture is an awareness of the origins of this unconventional warfare organization and the missions for which it was designed. After laying this foundation, this study will examine the shift to

\footnotetext{
${ }^{14}$ Paula Willoquet-Maricondi, "Full-Metal-Jacketing, or Masculinity in the Making," Cinema Journal 33, no. 2 (Winter 1994): 6.

${ }^{15}$ Andrew J. Bacevich, The New American Militarism: How Americans Are Seduced by War (New York: Oxford University Press, 2005), 97. Bacevich is referring to American myth writ large, the "stories created to paper over incongruities and contradictions that pervade the American way of life." However, the frontier myth is, as previously discussed, one of the most enduring of these myths.
} 
counterinsurgency warfare that was championed by the Kennedy administration. Government documents and official speeches show the early and consistent focus President Kennedy placed on counterinsurgency as part of his doctrine of flexible response to the threat of communist aggression. Counterinsurgency was seen as a remedy to the warning posed in The Ugly American, a 1958 book Kennedy admired and accepted at face value, along with the exhortations of U.S. Air Force Colonel Edward Lansdale, whose ideas on counterinsurgency were also integral to Kennedy's appreciation of the doctrine. At the behest of the Commander in Chief, the army moved to develop training programs and doctrine that would align with the new president's vision. Army publications show a desire to satisfy the president's demand, even if they did not indicate unanimous agreement with his strategy.

This discussion then lays the foundation for an examination of the creation and evolution of the Green Beret mythology, which will be explored through a broad study of popular American culture. Contemporary media reports, novels, a hit song, movies, toys, and comics reveal the multitude of ways in which distinct groups were sold, and bought into, the myth of the Green Berets. In many ways, this commodification of elite soldiers demonstrate how they came to be known as "the soldier of the New Frontier," as a U.S Army publication stated in $1961 .{ }^{16}$ Even those who propagated the myth oftentimes were seduced by it, as was author Robin Moore, who in researching The Green Berets developed a lifelong passion for the men of the Special Forces. Michael Cimino, the Academy Award-winning director of The Deer Hunter, claimed to have been a "medic with a Green Beret unit," and that these men had influenced the very spirit of

\footnotetext{
${ }^{16}$ Charles A. Dodson, “Special Forces," ARMY, June 1961, reproduced in Special Warfare, U.S. Army, Department of the Army (US Government Printing Office, 1962), 52.
} 
his film. ${ }^{17}$ However, it was later revealed that he had never had any connection with the Green Berets, showing just how powerful their mythology remained, even in the 1970s, an era known more for disillusionment of than admiration for the military. ${ }^{18}$ An exploration of these frequently overlooked aspects of myth-making will contribute to a fuller understanding of the role myths play in perpetuating society's notions of militarism, masculinity, and cultural primacy.

While myth might be the "language in which a society remembers its history," it is dangerous for precisely that reason. ${ }^{19} \mathrm{~A}$ society remembers its history in the manner it desires, which can be decidedly ahistorical. Therefore, in addition to exploring the development of the myth of the Green Berets, it is critical that we also examine their history and the reality of the war they fought in Vietnam. One window into this history is the monthly magazine published by $5^{\text {th }}$ Special Forces Group in Vietnam. Running from 1966 until 1970, when the Civilian Irregular Defense Group (CIDG) program was ended, they offer a remarkable view into the missions, priorities, values, and mindset of the Special Forces soldiers. While these magazines present a more informal vibe than do most unit publications, they are, nonetheless, official publications and therefore present only the "truth" the commanders saw fit to present to their audience: the operational vision Special Forces had of itself. These magazines will be supplemented with oral histories, letters, memoirs, and poems written by Special Forces veterans. In conjunction, these primary sources reveal a complicated relationship with the mythology. While some accounts bolster the myth, other soldiers found themselves disillusioned by the disparity between their perceived mission and the reality of the war they encountered. And disillusionment was not the

\footnotetext{
${ }^{17}$ Michael Cimino, American Cinematographer 50, no. 10 (October 1978): 1032. Cimino repeated the claim in an interview with the New York Times, see Leticia Kent, "Ready for Vietnam? A Talk with Michael Cimino," New York Times, December 10, 1978.

${ }^{18}$ See Dave Itzkoff, “Michael Cimino, Director of 'The Deer Hunter' and 'Heaven's Gate,' Dies at 77,” New York Times, July 2, 2016.

${ }^{19}$ Slotkin, Gunfighter Nation, 655.
} 
sole province of those who volunteered for Special Forces in the hopes of being a warrior of the New Frontier. Many veterans who enlisted expecting to replicate the derring-do of Moore's novel were similarly frustrated by the unglamorous civic action projects they found themselves involved in. This conflict exists at the heart of Special Forces and counterinsurgency warfare in general.

Before beginning an examination of the mythology however, we turn first to the means and purposes for which Special Forces was established. 


\section{The Origins of Special Forces and Counterinsurgency Warfare}

The Special Forces trace their origins to World War II and the Operational Groups of the Office of Strategic Services (OSS). ${ }^{20}$ The OSS was a civilian organization, headed by William "Wild Bill” Donovan, though it was primarily staffed with military personnel and reported to the Joint Chiefs of Staff. It had the strong support of President Franklin D. Roosevelt, support which proved to be crucial for the relative successes the OSS teams achieved. Much of the military leadership was averse to integrating them into operational planning due to the unconventional nature, and civilian control, of the teams. ${ }^{21}$ The friction between the military brass and the OSS is essential to understanding the subsequent development of the Green Berets myth, for this romanticization of breaking free from the tradition-bound military mindset would later become a fundamental element in the mythology.

While the OSS, writ large, was involved in various activities, such as espionage, counterintelligence, and psychological warfare, it was the Operational Groups that were to prove the progenitor of the Special Forces. ${ }^{22}$ Operating behind enemy lines as nuclei for guerrilla

\footnotetext{
${ }^{20}$ See John Whiteclay Chambers II, OSS Training in the National Parks and Service Abroad in World War II (Washington, DC: US National Park Service, 2008), https://www.nps.gov/parkhistory/online_books/oss/. While the OSS Special Operations Branch was originally assigned the missions of "sabotage, guerrilla warfare, and psychological operations," the Operational Group Command was formed for the primary purpose of directing guerrilla warfare, which resulted in some overlap in operational responsibility. However, unlike the covert two- to three-man Special Operations teams which often included civilian operators, the Operation Group personnel were all uniformed soldiers who worked in fifteen-man "sections" and received specialized training. See Nathan C. Hill, "Sowing Dragon's Teeth: OSS Operational Groups of World War II," Military Review (July-August 2013), 33.

${ }^{21}$ Charles M. Simpson III, Inside the Green Berets: The First Thirty Years, A History of the U.S. Army Special Forces (Novato, CA: Presidio Press, 1983), 12-13.

${ }^{22}$ Alfred H. Paddock, Jr., U.S. Army Special Warfare: Its Origins, Rev. ed. (Lawrence, KS: University of Kansas Press, 2002), 35; Chambers, OSS Training in the National Parks, 1; and Michael McClintock, Instruments of
} 
warfare units, these unconventional warfare teams comprised personnel selected for their foreign language abilities who were trained in the same skills that would come to make up the Special Forces training curriculum: weapons, demolitions, close-quarters combat, communications, parachuting, and organizing and training indigenous resistance groups. ${ }^{23}$

During World War II, OSS personnel were involved in a variety of guerrilla warfare missions throughout Burma, North Africa, China, the Philippines, Thailand, Europe, and the South Pacific, and many of the early proponents and leaders of Special Forces came from their ranks. ${ }^{24}$ At the end of the war, the OSS was unceremoniously dissolved, never having gained the legitimacy needed for inclusion into the larger military community. It would not be until the advent of the Cold War that the unconventional capabilities the OSS had embraced in World War II would once again be called upon.

In the early post-war years, as tension between the United States and the Soviet Union mounted, unconventional warfare again became a subject of interest for military and civilian planners. ${ }^{25}$ The National Security Council assigned responsibility for "subversion against hostile states," including supporting anti-Communist guerrillas, to the Central Intelligence Agency in 1948. ${ }^{26}$ However, the Army wanted no part in covert activities and moved first to rebuild its psychological warfare capabilities. ${ }^{27}$ The Army Chief of Psychological Warfare, Brigadier General Robert McClure, began planning for the development of a formal unconventional

Statecraft: U.S. Guerrilla Warfare, Counterinsurgency, and Counterterrorism, 1940-1990 (New York: Pantheon Books, 1992), 26.

${ }^{23}$ Paddock, U.S. Army Special Warfare, 28; Hill, "Sowing Dragon's Teeth," 33; see Chambers, OSS Training in the National Parks, 52-83 for an interesting examination of National Parks sites used for training OSS personnel.

${ }^{24}$ The most well-known of these are Robert McClure, Russell Volckmann, and Aaron Banks. See Melvin Russell Blair, "Toughest Outfit in the Army," Saturday Evening Post, May 12, 1956, 89.

${ }^{25}$ Simpson, Inside the Green Berets, 16.

${ }^{26}$ Paddock, U.S. Army Special Warfare, 68.

${ }^{27}$ For a discussion of the Army's aversion to covert operations, see McClintock, Instruments of Statecraft, 29; for a detailed study of the history of the Army's psychological warfare operations and the program's instrumentality in the genesis of Special Forces, see Paddock, U.S. Army Special Warfare, 118-139. 
warfare program, which would be "in the OSS pattern of tiny units with the prime mission of developing, training, and equipping the guerrilla potential deep in enemy territory." ${ }^{28}$ McClure's team, "hand-picked because of their background in guerrilla warfare," according to one team member, formulated doctrine, developed training plans, and prepared studies that culminated in the activation of the first Special Forces group in $1952 .{ }^{29}$

If, as historian Roger Beaumont has argued, "modern elite units have been children of the storm, products of crisis and instability," then the Cold War is the father of Special Forces and their earliest orientation was squarely upon Europe. ${ }^{30}$ Early recruiting efforts were split between the United States and Europe, with one Army general complaining that the Pentagon was "milking off resolute men of a distinctive breed for a cops-and-robbers outfit." "31 Word soon spread of the new unit, approximately 800 slots were filled, and the 10th Special Forces Group deployed to Bad Tolz, West Germany, ready to work with resistance groups behind the Iron Curtain in the event of war. ${ }^{32}$

Because the mythology is heavily centered on the idea of these men as "guerrilla experts" and the "best combat troops in the Army," at least according to most media accounts, it is necessary to examine their training to understand the origins of this belief. ${ }^{33}$ Colonel Aaron Bank, the first commander of the Group, stated that he applied his OSS background to the

\footnotetext{
${ }^{28}$ Paddock, U.S. Army Special Warfare, 120, quoting Colonel Aaron Bank.

${ }^{29}$ Blair, "Toughest Outfit in the Army," 89; and Paddock, U.S. Army Special Operations, 139.

${ }^{30}$ Roger A. Beaumont, Military Elites (New York: Bobbs-Merrill Company, 1974), 4. Author and Special Forces veteran Charles Simpson stated Special Forces was "born out of a fear of the universally expected World War III and Soviet strength in Europe, bitter experience in Korea, interservice rivalry, and the beliefs and determination of a handful of proponents." Simpson, Inside the Green Berets, 18-19. Other works that mention the Europe-focused orientation of the Special Forces' early years include Thomas K. Adams, U.S. Special Operations Forces in Action: The Challenge of Unconventional Warfare (Portland, OR: Frank Cass, 2001), 56-57; and Paddock, U.S. Army Special Warfare, 153.

${ }^{31}$ Blair, "Toughest Outfit in the Army," 89.

${ }^{32}$ Adams, U.S. Special Operations Forces in Action, 57; and Simpson, Inside the Green Berets, 34.

${ }^{33}$ William Beecher, "Jungle Fighters," Wall Street Journal, August 6, 1964; and "The Men in the Green Berets," Time, March 2, 1962, 18. For information on Special Forces training manuals during this period, see McClintock, Instruments of Statecraft, 44.
} 
formation of Special Forces "training, doctrine, concepts, planning, standards, and goals. The OSS legacy was our bible." ${ }^{34}$ This meant the fifteen-man Operational Group was retained as a foundational construct, though slightly modified into the eventual twelve-man team comprising two officers and ten enlisted men.

All men were to be qualified parachutists, trained in their primary occupational specialty, and cross-trained in the specialties of their teammates. ${ }^{35}$ This included communications, demolitions, heavy and light weapons, field medicine, and operations and intelligence. Because these teams would be based behind enemy lines, organizing and training guerrilla fighters, their training necessarily included infiltration techniques, hand-to-hand combat, techniques of instruction, escape and evasion, and other such skills. Prior to deployment, the team studied the language and culture of the region and familiarized themselves with the operational environment. ${ }^{36}$

The myth of the Green Berets is commonly understood as a Kennedy-era creation, but its inception can be traced to the 1950s. There are almost no media accounts of the Special Forces in the first year of the Group's existence; it was not until 1953 that newspapers began mentioning with any regularity the training, promotions, traffic accidents, and weddings of men assigned to the 10th Special Forces Group. ${ }^{37}$ However, nothing was ever mentioned about what exactly

\footnotetext{
${ }^{34}$ Adams, U.S. Special Operations Forces in Action, 56, quoting a letter from Bank to the author.

${ }^{35}$ Officers did not receive the same level of training the enlisted men did, instead attending an officer's familiarization course. The training courses for occupational specialties varied in length according to the specialty, but the overall training cycle lasted more than a year and was the longest for medics. See Simpson, Inside the Green Berets, 36-38.

${ }^{36}$ The initial teams did not receive language training, as many of the men were immigrants who spoke multiple languages, giving "the outfit a Foreign Legion flavor," according to one veteran. See Simpson, Inside the Green Berets, 26.

${ }^{37}$ See, for example, "Paratrooper Hero of Europe, Korea, Dies in his Car," Boston Globe, April 9, 1953; "Model GI to Visit Fort Mac," Atlanta Constitution, May 7, 1953; "In Special Forces...," Napa Valley Register, September 15, 1953; "2 GIs Killed, 3 Hurt as Truck Overturns," Knoxville News-Sentinel, September 20, 1953; and "Sergeant Views Top Levels," Raleigh News and Observer, September 29, 1953.
} 
Special Forces was, or what they did, until 1954, when an Army spokesman was quoted saying "the special forces groups (airborne) are cellular units organized to conduct operations within or behind enemy lines, on a sustained basis, for military purposes." ${ }^{" 38}$

By 1955, the "distinctive green beret" was remarked upon for the first time in the press as the "trademark of special brand of new soldier." ${ }^{39}$ One nationally-syndicated article included a photograph of two men with rifles and binoculars, crouched in the snow, the "jaunty green beret only he among all U.S. Army soldiers may wear," lending a dashing air to the pair. The training of the "Army's most versatile soldier" was described in detail, as was his lineage to the OSS teams, his ability to live off the land-“porcupine furnishes rich meat"-and speak multiple languages. ${ }^{40}$ Of the journalists who did cover these modern frontier heroes, most focused on the soldiers' small unit operations, mastery of the wilderness, weapons' skills, parachute training, and missions into enemy territory. None of these early articles emphasize the Green Berets' lethality or disregard for convention, conveying them instead in a somewhat chaste light.

This would all change with the publication of two Scripps-Howard newspaper articles in 1956 under the headlines "Men in Green Berets Are Deterrent to War" and "Killing Routine to Green Berets." ${ }^{41}$ In language that bordered on lurid, the author, Albert M. Colegrove, described these men as "hard, lean fighters of many tongues and talents. Trained as sharp as a dagger's

\footnotetext{
38 “Army Trains 'Hunter-Killer' Teams to Fight Foe in Rear," Spokesman-Review, July 11, 1954. Army recruiting articles in 1954 offer direct enlistment into Special Forces, though no details are given as to what these soldiers do. See "Army Elite Corps Accepting Men," Charlotte News, September 4, 1954. The Army also recruited veterans for the Special Forces Reserves, telling candidates the organization "will be different from any they have been assigned to previously." See "Special Forces Reserve Unit to Be Activated," Robesonian, December 1, 1954.

39 "Army Reservists Training," Raleigh News and Observer, November 4, 1955; and "Army's Green Beret Is Trademark of Special Brand of New Soldier," Escanaba Daily Press, December 14, 1955.

40 “Army's Green Beret Is Trademark of Special Brand of New Soldier," Escanaba Daily Press, December 14, 1955.

${ }^{41}$ Albert M. Colegrove, "Men in Green Berets Are Deterrent to War," Knoxville News-Sentinel, February 28, 1956; and Albert M. Colegrove, "Killing Routine to Green Berets," Pittsburgh Press, March 1, 1956. Albert Colegrove, a Scripps-Howard staff writer, would go on to write the six-part series "Our Scandal in Vietnam" in 1959 which sparked a Congressional investigation into the veracity of his claims.
} 
point. Ready, now, if war comes, to plunge behind the Iron Curtain and fan the flames of rebellion." Their abilities were "astonishing" and their skills "an almost-incredible mixture of those needed by the assassin, the frontiersman and the atomic-age soldier." ${ }^{42}$ Colegrove did cover their language skills and grueling training regimens, but his excitement is most evident when he discussed the many different way these soldiers could kill: "swift, silent throat-cutting in the dark" or "skull-cracking judo blow."43 These articles are also notable because they are based on a personal interview with the commander of the Special Forces training center, who allowed Colegrove to inspect one of his teams and their equipment. Whether Colegrove was given access for recruiting purposes or to raise public support for the fledgling organization, Special Forces had officially stepped out of the shadows. ${ }^{44}$

By the mid- to late-1950s, the men of the Green Berets had become known as "Fort Bragg's guerrillas" and their training facility, the Psychological Warfare School, prepared and updated Army field manuals on offensive guerrilla warfare. ${ }^{45}$ However, this did not automatically translate into an acceptance of the counterguerrilla mission. ${ }^{46}$ In 1954 , the

\footnotetext{
${ }^{42}$ Albert M. Colegrove, "Men in Green Berets Are Deterrent to War," Knoxville News-Sentinel, February 28, 1956.

${ }^{43}$ Albert M. Colegrove, "Killing Routine to Green Berets," Pittsburgh Press, March 1, 1956; and Albert M. Colegrove, "Men in Green Berets Are Deterrent to War," Knoxville News-Sentinel, February 28, 1956.

${ }^{44}$ Another article, published in the Saturday Evening Post in 1956, highlighted Special Forces and their elite capabilities. Written by a retired Army colonel, the author established his bona fides with a half-page reflection of the moonlight killing of a Japanese soldier in the jungles of Burma: "I grabbed the trench knife from the sergeant's hand and plunged it into the sentry with all my strength. The struggle ended." The five-page article went on to enumerate the many abilities of Special Forces soldiers and the rigorous training they underwent. The article opined that "Guerrilla warfare is no game for PX soldiers or men unwilling to suppress their ethics in the interest of survival." Melvin R. Blair, “Toughest Outfit in the Army," Saturday Evening Post, May 12, 1956, 41. In his book War Story, Jim Morris cited the Post article as his motivation for joining Special Forces. Morris edited Green Beret magazine in Vietnam from November 1967 to June 1968 and published War Story in 1979. Jim Morris, War Story (Boulder, CO: Paladin, 1979), 160.

${ }^{45}$ See Bem Price, "Fort Bragg's Master Troublemakers," Raleigh News and Observer, June 21, 1959; and "Main Psywar School Area Special Warfare Center," Clarksville Leaf-Chronicle, August 13, 1958, in which Special Forces is called "a paratroop guerrilla warfare organization."

${ }^{46}$ See Andrew J. Birtle, U.S. Army Counterinsurgency and Contingency Operations Doctrine, 1942-1976 (Washington, DC: US Government Printing Office, 2006), 149-150 for the debate within Special Operations over responsibility for counterguerrilla warfare. While Brigadier General McClure was an enthusiastic supporter of the counterguerrilla mission for Special Forces, his departure in 1954 led to a disinterest in counterguerrilla warfare that continued through the $1950 \mathrm{~s}$.
} 
Psychological Warfare School argued that "the tactics, doctrine and the conduct of anti-guerrilla operations is not the responsibility or mission of Special Forces." ${ }^{47}$ While this argument did not prevail, it did mean that counterguerrilla warfare received little attention within Special Forces until the 1960s. ${ }^{48}$ However, as military historian Andrew Birtle argues, a conflux of developments in the years leading up to John F. Kennedy's election resulted in a growing acceptance within the Army of the importance of counterinsurgency doctrine, though this was by no means a unanimous consensus. ${ }^{49}$ Nevertheless, Walt Rostow's "modernization" theories of economic development, decolonization, communist-backed revolutions, and ideas of limited warfare all paved the way for the eventual ascendancy of President Kennedy's support of counterinsurgency and the Green Berets as the vanguard of military action. ${ }^{50}$

In July 1960, Kennedy delivered his New Frontier speech while accepting the Democratic presidential nomination. Using mythical rhetoric, he spoke of a "new frontier" in which American pioneers would battle threats and perils to realize novel promises and opportunities. While this new frontier-much like the old-was full of hazards, the main danger was the "single-minded advance of the communist system." The nation had to meet this threat squarely, proving to the world that American ideology would prevail for "mastery" of "men's

\footnotetext{
${ }^{47}$ McClintock, Instruments of Statecraft, 48, see footnotes 99 and 100 on page 477 for detailed information on Army memoranda on this subject.

${ }^{48}$ Birtle, U.S. Army Counterinsurgency, 150. Likewise, historian Gregory A. Daddis argues that many Army officers in the Kennedy era considered counterinsurgency a "topic worthy of study and debate." See Gregory A. Daddis, "Eating Soup with a Spoon: The U.S. Army as a 'Learning Organization' in the Vietnam War," Journal of Military History 77 (January 2013): 236.

${ }^{49}$ Birtle, U.S. Army Counterinsurgency, 161-165. Counterguerrilla warfare is military action taken to defeat guerrilla forces. Counterinsurgency combines counterguerrilla warfare with political and economic programs with the aim of pacifying the population who would otherwise serve as recruits for insurgent warfare. While these terms are distinct, they are often used interchangeably by both military leaders and historians. See Birtle, U.S. Army

Counterinsurgency, 4.

${ }^{50}$ On Rostow and the relationship between modernization theory and military policies, see Michael Latham, Modernization as Ideology: American Social Science and "Nation Building" in the Kennedy Era (Chapel Hill: University of North Carolina Press, 2000).
} 
minds." ${ }^{51}$ In his inaugural address in January 1961, Kennedy returned to the theme of American exceptionalism triumphing over global threats. While avoiding specific reference to "battle" or "communism," he spoke of a "long twilight struggle" to defend freedom "in its hour of maximum danger." This was a historic engagement, one "only a few generations" had ever been part of, and the import was clear: the world was watching and America had to prove her worthiness. ${ }^{52}$

While these speeches gained national attention, much of Kennedy's thinking on counterinsurgency predated his election as president. ${ }^{53}$ By all accounts, he was determined to avoid the mistakes of American foreign aid as represented in The Ugly American, a 1958 political fiction work by Eugene Burdick and William Lederer, that he publicly praised and gifted to colleagues. Kennedy sought a more culturally sensitive interventionism, embracing the ideas of Maxwell Taylor and Edward Lansdale. ${ }^{54}$ The imperative of maintaining flexibility in responding militarily to communist aggression and countering it through actions and programs designed to elicit goodwill would crystallize in his counterinsurgency policies as president. ${ }^{55}$ It was this aspect of supposed benevolence and cultural awareness that was crucial in forming the initial myth of the Green Berets.

\footnotetext{
${ }^{51}$ John F. Kennedy, “The New Frontier Acceptance Speech,” July 15, 1960, JFKCAMP1960-1032-027-p0001, John F. Kennedy Presidential Library and Museum.

${ }^{52}$ John F. Kennedy, "Inaugural Address," January 20, 1961, USG-17, John F. Kennedy Presidential Library and Museum.

${ }^{53}$ On Kennedy's ideology and his approach to war, see Lawrence Freedman, Kennedy's Wars: Berlin, Cuba, Laos, and Vietnam (New York: Oxford University Press, 2000).

${ }^{54}$ For a discussion of Lansdale and Taylor and their influence in Kennedy's administration, see chapter 9 in Steven Watts, JFK and the Masculine Mystique: Sex and Power on the New Frontier (New York: St. Martin's Press, 2016). ${ }^{55}$ For Taylor's ideas on flexible response, see Maxwell D. Taylor, The Uncertain Trumpet (New York: Harper \& Brothers, 1960). A detailed study of Taylor's theories can be found in Ingo Trauschweizer, Maxwell Taylor's Cold War: From Berlin to Vietnam (Lexington, KY: University of Kentucky Press, 2019). For a thorough, yet problematic, study of Lansdale's life and counterinsurgency ideas see Max Boot, The Road Not Taken: Edward Lansdale and the American Tragedy in Vietnam (New York: Liveright Publishing, 2018).
} 
Upon taking office, Kennedy quickly moved to ensure the armed forces were prepared to respond to communist-sponsored guerrilla warfare. ${ }^{56}$ Within two weeks of taking office, the president requested that the Secretary of Defense "examine means for placing more emphasis on the development of counter-guerrilla forces. ${ }^{, 57}$ In response, an increase of 3,000 Special Forces soldiers and a $\$ 19$ million budget augmentation was proposed to develop "a counter-guerrilla capability." ${ }^{58}$ The conventional Army's initial reluctance to embrace unconventional warfare thus gave way before the new President's sweeping counterinsurgency initiatives. ${ }^{59}$

Kennedy continued his advocacy for counterinsurgency before a Joint Session of Congress on May 25, 1961. Again propounding the nation's leadership role as the defender of freedom, he returned to his martial campaign rhetoric and warned of the battle being waged for "minds and souls" in the "whole southern half of the globe." ${ }^{\prime 60}$ Heeding the exhortation of The Ugly American, Kennedy placed a "new emphasis" on the "special skills and languages which are required to work with local populations." Kennedy requested additional funding for Special Forces as part of a flexible response to counter communist aggression. Congress approved the request and included an additional $\$ 7.5$ million for research and development of Special Forces equipment. ${ }^{61}$

\footnotetext{
${ }^{56}$ According to Roger Hilsman, "What are we doing about guerrilla warfare?" was one of the "first questions Kennedy asked his aides when he became President." Roger Hilsman, To Move a Nation: The Politics of Foreign Policy in the Administration of John F. Kennedy (Garden City, NY: Doubleday, 1967), 413.

${ }^{57}$ Papers of John F. Kennedy, Presidential Papers, National Security Files, Meetings and Memoranda, National Security Action Memorandum (NSAM): NSAM 2, "Development of Counter-Guerrilla Forces," February 3, 1961, JFKNSF-328-003, John F. Kennedy Presidential Library and Museum.

${ }^{58}$ Papers of John F. Kennedy, Presidential Papers, National Security Files, Meetings and Memoranda, Secretary of Defense Robert S. McNamara to the Special Assistant to the President for National Security Affairs McGeorge Bundy, "Development of Counter-Guerrilla Forces," Response to NSAM 2, February 23, 1961, JFKNSF-328-003, John F. Kennedy Presidential Library and Museum.

${ }^{59}$ See Birtle, U.S. Army Counterinsurgency, 225-227, for a more detailed examination of the Army's response to Kennedy's counterinsurgency initiatives both within Special Forces as well as larger, conventional units.

${ }^{60}$ John F. Kennedy, "Special Message to Congress on Urgent National Needs," May 25, 1961, JFKPOF-034-030, John F. Kennedy Presidential Library and Museum.

61 “Congress Increases Kennedy Defense Budget," CQ Almanac 1961, 17 ${ }^{\text {th }}$ ed., 142-47 (Washington, DC:

Congressional Quarterly, 1961), http://library.cqpress.com/cqalmanac/cqal61-1372707.
} 
An additional element of this new type of warfare, as identified by the president while speaking to the graduating class at West Point in 1962, was the inclusion of "diplomatic, political and economic" problems into the military realm. ${ }^{62}$ The National Security Council called on the armed forces to recognize the importance of "counter-insurgency problems" and to align their “organization, training, equipment and doctrine" accordingly. ${ }^{63}$ As historian Richard Betts describes it, "the services rushed to see which could accommodate [the president] fastest."

As early as 1960 , the unconventional warfare community had noted in policy papers that in revolutionary warfare the "assumption that the solution of the problem is solely a military one has been proven erroneous." ${ }^{95}$ Any operations undertaken to defeat local insurgents must necessarily emphasize "political, psychological and economic actions." ${ }^{96}$ However, this additional aspect of counterinsurgency, the focus on addressing the root cause, was not commonly understood, even within the Special Forces community. It was not until Kennedy's push for countering communist-led insurgencies that this distinction became clearer in Army publications. Not only were these ideas incorporated into subsequent doctrine and training manuals, but numerous Army-affiliated publications began highlighting Special Forces as the preeminent counterinsurgency practitioners. One of these, the March 1962 edition of Army magazine, featured a green beret on the cover over the caption "Big Push in Guerrilla Warfare: The Army Beefs-up Its Counterinsurgency Posture." ${ }^{97}$ The magazine featured an article written

\footnotetext{
62 "Transcript of the President's Address to the Graduating Class at West Point," New York Times, June 7, 1962.

${ }^{63}$ Papers of John F. Kennedy, Presidential Papers, National Security Files, Meetings and Memoranda, "Establishment of the Special Group (Counter-Insurgency)," NSAM 124, January 18, 1962, JFKNSF-333-016, John F. Kennedy Presidential Library and Museum.

${ }^{64}$ Betts, Soldiers, Statesmen, and Cold War Crises, 129.

${ }^{65}$ Department of the Army, Office of the Director of Strategic Plans and Policy, Special Warfare Division, Counter Insurgency Operations: A Handbook for the Suppression of Communist Guerrilla/Terrorist Operations, December 1, 1960, 3, in Item 2620125001, Ronald Rodeck Collection, Vietnam Center and Sam Johnson Vietnam Archive, Texas Tech University.

${ }^{66}$ Ibid., 39.

${ }^{67}$ Army 12, no. 8 (March 1962).
} 
by General Maxwell Taylor titled “Our Changing Military Policy,” an article on Khrushchev's wars of national liberation, numerous articles on Special Forces and guerrilla warfare, and brief biographies of the "young moderns" who were leading Special Forces.

Also in 1962, the Army published a large-format glossy booklet devoted to its special warfare capabilities ${ }^{68}$ A foreword by the Secretary of the Army told commanders to "draw upon this material in their training and Troop Information programs, for proficiency in Special Warfare is an indispensable requirement for the effective soldier and combat leader in today's Army." ${ }^{99}$ Within the booklet were studies of guerrilla fighters throughout history, primers on Mao and Che Guevara, a recommended reading list on counterinsurgency and unconventional warfare, and a reprint of Walt Rostow's speech at the Army Special Warfare Center. ${ }^{70}$ The publication took pains to define common terminology, noting that counterinsurgency was a combination of counter-guerrilla operations and "civic action." This key term was soon to become the buzz-word of Special Forces in Vietnam and was broadly defined as "any action performed by military forces of a country, utilizing military manpower and skills in cooperation with civil agencies, authorities, or groups, that is designed to improve the economic or social conditions of that country." 71

The main focus of the booklet was the training, capabilities, and missions of the Green Berets-the "soldier of the New Frontier."72 While these men are praised as "pioneer types," the Army clearly attempted to downplay any notion of Special Forces as "outside" the conventional

\footnotetext{
${ }^{68}$ This publication included many previously published articles excerpted from magazines such as Army, Male, and Military Review.

${ }^{69}$ Special Warfare, U.S. Army, Department of the Army (US Government Printing Office, 1962), 5.

${ }^{70}$ In 1956, the Psychological Warfare Center had been renamed as the Special Warfare Center and School. See Paddock, U.S. Army Special Warfare, 155 and Brigadier General William P. Yarborough, "U.S. Army Special Warfare Center," in Special Warfare, 61.

71 "Use the Right Word," in Special Warfare, 8-9. This publication and the Army magazine discussed in the previous paragraph were both in Kennedy's papers at the time of his death.

${ }^{72}$ Charles Dodson, "Special Forces," in Special Warfare, 52.
} 
Army. They are a "strictly military outfit," subject to "the same disciplinary code as other soldiers." 73 The publicity they have received is "unfortunate" and inaccurate, for the Special Forces soldier wears an "ordinary combat uniform," and is "neither a commando nor a cloakand-dagger agent," but a conventional soldier with an unconventional mission. ${ }^{74}$ Despite these efforts to assuage conventional commanders that Special Forces worked within the military structure, the growing public interest in the Green Berets and the media spotlight that was soon to shine on them would only increase tensions in the years to come.

President Kennedy's visit to Fort Bragg in October 1961 played a critical role in establishing the mythology of the Green Berets, for it is after this visit that he issued the order that made the green beret part of their official uniform. While Kennedy spent a majority of his visit reviewing and addressing conventional units, his visit included a forty-minute demonstration by the Special Warfare Center and School. ${ }^{75}$ A series of parade-style trailers commenced the proceedings, with men and equipment showcasing different Special Warfare capabilities, such as Special Forces training and team configurations, elements of counterinsurgency warfare, civic action projects, and psychological operations. Demonstrations then began of hand-to-hand combat techniques, rappelling, scuba insertion, and a simulated guerrilla attack. The show culminated with a fanciful demonstration of a backpack rocket and a leaflet-drop featuring the president's image with the words "Mr. President you call the tune."76

\footnotetext{
${ }^{73}$ Charles Dodson, "Special Forces," in Special Warfare, 53, 58.

${ }^{74}$ Captain Robert B. Asprey, "Special Forces: Europe," in Special Warfare, 95.

75 In total, Kennedy spent over five hours at Fort Bragg. For a detailed account of Kennedy's visit, see Charles H. Briscoe, "JFK Visits Fort Bragg: A Photo Essay," Veritas 14, no. 2 (2018): 32-42. An example of newspaper coverage of the visit includes Richard Dudman, "Kennedy Sees Cold, Hot War Demonstration," St. Louis PostDispatch, October 13, 1961.

${ }^{76}$ See Briscoe, "JFK Visits Fort Bragg," 37-40 for images and photographs of the Special Operations display. Briscoe's article also includes photographs of Kennedy's review of conventional units at Fort Bragg.
} 
Scholars debate whether Kennedy's visit was a publicity stunt by the president to drum up media interest in the Green Berets or an attempt by the military to sell the president on the use of Special Forces. In reality, it was probably both. Kennedy's interest in the Green Berets predated his trip to Fort Bragg and he took a personal interest in them, commanding they wear their berets for his visit. ${ }^{77}$ Likewise, Special Forces offered the Army a means of implementing the president's counterinsurgency mandate, allowing them to secure missions and funding that might have been diverted elsewhere. Two months after Kennedy visited Fort Bragg, the Department of the Army officially authorized Special Forces to wear the green beret, linking forever the young president and these elite soldiers in American military mythology. ${ }^{78}$

\footnotetext{
${ }^{77}$ Regarding Kennedy's interest in the Green Berets, see Arthur M. Schlesinger, Jr., A Thousand Days: John F. Kennedy in the White House (New York: Houghton Mifflin, 1965, 2002), 340-342; Douglas S. Blaufarb, The Counterinsurgency Era: U.S. Doctrine and Performance, 1950 to the Present (New York: Macmillan, 1977), 55-56; Hilsman, To Move a Nation, 415; and Hugh Sidey, John F. Kennedy, President (New York: Atheneum, 1964), 205.

${ }^{78}$ Berets had been worn by Special Forces since 1952 and had been authorized by Special Forces command. However, in 1956, the commanding general of Fort Bragg prohibited their use on post. While they were still used in the field and on deployments, it was not until the president's visit and his praise of the green beret as a "symbol of excellence" that Army Regulations officially made them a part of the uniform for Special Forces. See Simpson, Inside the Green Berets, 31-32. Berets became somewhat of a fashion trend in early 1962, as noted in the New York Times, where it was said "there is hardly a subway car or a bus or a block in which the soft woolen cap with no brim and the tiny 'tail' on top does not appear on one or more heads." The article featured an illustration of a Special Forces soldier parachuting from a plane, green beret affixed upon his head, armed with a grenade, pistol, and knife. Milton Bracker, "Becomingly Basque, the Beret," New York Times, February 11, 1962.
} 


\section{The Creation of the Green Beret Myth, 1961-1964}

The first media coverage of Special Forces during the Kennedy administration began appearing only a few months after his election and read primarily like joint press releases from the White House and Pentagon. In March 1961, an article in Time stated that Special Forces "blossomed from the shadows" after Kennedy commanded the Pentagon to increase its unconventional warfare capabilities. The "guerrillas" of the Special Forces were presented as versatile warriors, skilled in all manner of weapons systems, even able to "talk knowingly about the principal Hungarian poets" should they deploy to Hungary. Their goal was to "elicit support from the local people by promises, threats, bribes, or by any other means." ${ }^{, 79}$ The notion of winning hearts and minds through good deeds or social reform projects had yet to make an appearance in the media coverage.

Popular Science also entered the pop culture craze, publishing an article that same year that highlighted the equipment and training of Special Forces and included many patently false statements, including calling them "teach-and-run soldiers" who "will never fire a shot at the enemy." 80 Another erroneous claim was that each Special Forces soldier would undergo every conceivable specialized training program, including arctic and jungle training, mountaineering, amphibious training, underwater demolitions, and ski training. ${ }^{81}$ By late 1961, Esquire noted the

\footnotetext{
79 “The American Guerrillas," Time, March 10, 1961, 19.

${ }^{80}$ Everett H. Ortner, "Special Forces: The Faceless Army," Popular Science, August 1961, 57.

${ }^{81}$ While many soldiers attended one or more of these programs, one would have been hard pressed to find a Special Forces soldier who had attended them all. See Simpson, Inside the Green Berets, 38; and Donald Duncan's review of The Green Berets in Ephemera, Ramparts 4, no. 10 (February 1966): 66. This misunderstanding-or exaggeration-
} 
stream of journalists who visited Fort Bragg had become steady enough to warrant "a standard show" for visiting television cameramen and magazine photographers. ${ }^{82}$ The New York Times called the emblem of the Special Forces "the Army’s leading status symbol."

Esquire took a different tack in its coverage, scoffing at media portrayals of the Green Berets as "a bunch of supermen" or "superspies." Instead, the magazine highlighted the unconventional nature of Special Forces and the animosity this engendered within the conventional Army. The reader was left with a thrilling impression that this group of "extraordinary soldiers," the stepchildren of Fort Bragg, were above the petty military concerns of starched uniforms and garrison duties. Also noted was their ability to serve in "underdeveloped areas" of the world, as had the heroes of The Ugly American. ${ }^{84}$ While development projects received only a brief mention, it was one of the first times that civic action was linked to Special Forces in the media.

For the most part, this early coverage did not mention counterinsurgency and its complementary socio-economic aid programs. Special Forces were instead presented as soldiers who fought as guerrillas against guerrillas or who trained others to do so. ${ }^{85}$ Medical aid was simply a means "to opening up a village for anti-guerrilla training," as a 1962 article in Commonweal explained. ${ }^{86}$ Time magazine noted that "carousing and consorting with native

of the Special Forces training program had existed since their formation. In the Kennedy era, however, it was to reach new extremes.

${ }^{82}$ George J. W. Goodman, “The Unconventional Warriors,” Esquire, November 1961, 131. The movie The Green Berets opens with a similar briefing/show for visiting journalists.

${ }^{83}$ A. M. Rosenthal, "Guerrilla Base Gets U.S. Priority," New York Times, September 10, 1961.

${ }^{84}$ George J. W. Goodman, “The Unconventional Warriors,” Esquire, November 1961, 130, 132.

${ }^{85}$ Examples of media coverage of Special Forces as guerrillas include Will Sparks, "Guerrillas in Vietnam," Commonweal, June 29, 1962, 345 ("Special Forces teams are not only anti-guerrilla fighters, of course: they are also guerrillas"); "U.S. Guerrillas: With Knife and Strangling Wire,” Time, May 24, 1962, 27 (“...expert guerrilla fighters from Special Forces"); and Milton Bracker, "Becoming Basque, the Beret," New York Times, February 11, 1962 ("United States Army Special Forces (guerrilla troops) with forest-green berets").

${ }^{86}$ Will Sparks, "Guerrillas in Vietnam," Commonweal, June 29, 1962, 344. 
women" was taboo, as "support of the local populace" was essential to the success of the Special Forces' guerrilla mission. ${ }^{87}$ Good deeds were thus seen as a means of securing access, not as part of a larger strategy of building confidence in the local government. Also rare in these early years was the use of the term "Green Berets." "Special Forces" continued to be the term preferred by the media in the early $1960 \mathrm{~s}$.

One publication that offered a detailed look into Special Forces during these relatively early years, and the politics of counterinsurgency, was the Saturday Evening Post. An April 1962 article, "Hot Weapon in the Cold War," claimed the Joint Chiefs of Staff had been caught unprepared by Kennedy's interest in guerrilla warfare. It was only "under prodding" that they "rallied to the idea of using Special Forces." The article cited Army field manuals and training handbooks, quoted Walt Rostow and Brigadier General Edward Lansdale, and repeated the assertions made in Popular Science of the training and wide-ranging expertise of "the finest soldiers in the United States Army." ${ }^{88}$ While the term counterinsurgency was never used, the social and political reforms necessary to counter guerrilla warfare were clearly laid out. And the source of these reforms was without doubt, for in the view of "most of the Special Forces men, the Army is the natural vehicle for progress in the underdeveloped world." 89

The images that frequently accompanied these articles contributed to a growing public interest in these "stealthy marauders" who wore the green beret. ${ }^{90}$ There were two distinct elements to this imagery, the first of which was the Special Forces' apparent embracing of a more primitive form of frontier warfare. Unlike media coverage of conventional military units, these were small groups of men, whose wilderness skills lent the articles an air of wistfulness, as

\footnotetext{
${ }^{87}$ Armed Forces, "The Men in the Green Berets," Time, March 2, 1962, 18.

${ }^{88}$ Joseph Kraft, "Hot Weapon in the Cold War," Saturday Evening Post, April 28, 1962, 88.

${ }^{89}$ Ibid., 91.

90 “The American Guerrillas," Time, March 10, 1961, 19.
} 
if they existed outside of cities and suburbs and the workaday drudgery of corporate life. Almost none of the photographs showed massive weaponry, large groups, or signs of civilization. ${ }^{91}$ They were primarily shots of a lone soldier-or a small number of them-communing with nature in her various elements: the woods, the water, or the air. A soldier was pictured eating a snake, parachuting over a pristine snow-clad landscape, diving in a mountain lake, rappelling down a cliff, or training in the forest. ${ }^{92}$ The imagery was that of Daniel Boone or Davy Crockett, men at ease in the wild frontier. The contrast to the American corporate white-collar manager could not have been clearer.

The second element of the imagery was the martial mastery of Special Forces soldiers. They might have been frontier soldiers, but they were modern frontiersmen who had brought the weapons of progress with them. Images of sophisticated infrared lamps and goggles, demolitions gear, radio equipment, and machine guns of all types established the Green Berets as the new kings of the wild frontier. But they were not merely masters of modern weaponry. Rather, as the articles made clear, these warriors had "a detailed knowledge of weapons ranging from the bow and arrow to the howitzer." 93 The perfect fusion of the tribal and the modern, the Green Beret was set to update frontier mythology in his image.

By the mid-1960s, Americans knew that Special Forces teams had been sent to Vietnam and that they were more than just advisors. The March 1963 cover of the Saturday Evening Post featured a Green Beret outside a burning village with the caption “I'm hit, I'm hit." The article

\footnotetext{
${ }^{91}$ The exception to this was when the layout of a Special Forces team was shown or when Brigadier General Yarborough was pictured with a detachment of his soldiers. See Everett H. Ortner, "U.S. Special Forces: The Faceless Army," Popular Science, August 1961, 56; and Joseph Kraft, "Hot Weapon in the Cold War," Saturday Evening Post, April 28, 1962, 90.

${ }^{92}$ See “U.S. Guerrillas: With Knife and Strangling Wire," Time, May 24, 1962, 27, 30; Everett H. Ortner, "U.S. Special Forces: The Faceless Army," Popular Science, August 1961, 57; and Joseph Kraft, "Hot Weapon in the Cold War," Saturday Evening Post, April 28, 1962, 88.

93 Joseph Kraft, "Hot Weapon in the Cold War," Saturday Evening Post, April 28, 1962, 88.
} 
reminded readers that "Americans are fighting a war in Vietnam," against "Communist guerrillas who hope eventually to take over all of Southeast Asia." Over fourteen pages of text and color photographs told the story of two Special Forces teams and the outposts they had established to beat back the threat. One of the outposts, described as "a front in the midst of enemy territory on the wild tropical frontier," was code-named "Nashville Frontier."94 The men played poker at night, bathed in streams whose serenity was broken only by sniper fire, patrolled the wilds of the jungle with native tribesmen, and fought back enemy attacks. Even in this early stage of involvement in Vietnam, Special Forces faced down the many foes who would soon become familiar to the American public: Army bureaucracy, guerrilla infiltration of village defense forces, and the deficiencies of the Vietnamese government. ${ }^{95}$ For an American public fearful of the global advance of communism, the Green Berets offered some small satisfaction that action was being taken to stem the tide.

Media coverage also began stressing the civic action programs implemented by Special Forces in such articles as "Fighting Is Secondary to Army Special Forces." Published in the New York Times, the article noted the "prevailing reputation" of the unit as a "Gung Ho outfit," but highlighted instead the training of these "elite soldiers" for a "delicate type of international diplomacy that few State Department officers get a chance to practice." While direct action was still a part of their mission, the article stressed that Special Forces mostly conducted medical training and outreach, schooling, and sanitation and construction projects. ${ }^{96}$

\footnotetext{
${ }^{94}$ Jerry A. Rose, "I'm Hit! I'm Hit!" Saturday Evening Post, 34-36.

${ }^{95}$ The Army was portrayed as inane due to the soldiers' ineligibility for the Combat Infantryman's Badge, an honor not given because of the advisory capacity under which the military was ostensibly operating. See Rose, "I'm Hit! I'm Hit!" 46.

${ }^{96}$ Jack Raymond, "Fighting Is Secondary to Army Special Forces," New York Times, December 23, 1964.
} 
The duality of their image, as both peerless warriors and soldier diplomats, allowed a broad cross-section of the public to support America's growing involvement in Vietnam. Even New York Times reporter David Halberstam, an early critic of America's strategy in Vietnam, wrote glowingly of the Green Berets in numerous articles published during this period. ${ }^{97}$ These "tough" men seemed "completely indifferent to danger" and had built their outpost in Dak Pek much as a "select crew of planners might build a village on a prairie." 98 He wrote of another Special Forces team, who lived in a compound nicknamed "Little Dienbienphu," as having an "awesome reputation" among the Vietnamese and Cambodians. ${ }^{99}$ Halberstam claimed the "Special Forces program has been successful beyond the expectations of even its most enthusiastic planners." He credited this success to Special Forces' recognition of the "social, political and medical as well as the military aspects" of their efforts. ${ }^{100}$

Despite the media coverage, the Green Berets would not saturate pop culture until after the publication of Robin Moore's book in 1965. However, these earlier years witnessed them making increasing appearances in films, television shows, and children's toys. One such toy, manufactured by Mattel, was a "Guerrilla Gun" that appeared in the 1963 Sears Catalogue. The gun fired in either single-shot or burst mode and could also be purchased in a set which included

\footnotetext{
${ }^{97}$ For an analysis of press coverage of the Vietnam War, see Daniel C. Hallin, The "Uncensored War:" The Media and Vietnam (Los Angeles: University of California Press, 1989); and chapter 16 in Phillip Knightley, The First Casualty: The War Correspondent As Hero and Myth-Maker From the Crimea to Iraq (Baltimore: Johns Hopkins University Press, 2004).

${ }^{98}$ David Halberstam, “Americans Hold Vietnam Outpost," New York Times, December 20, 1962.

${ }^{99}$ David Halberstam, "G.I.'s Set Up a Training Camp in Midst of Vietcong Sanctuary,” New York Times, February 13, 1963.

${ }^{100}$ David Halberstam, "Salt Helps U.S. Win Vietnamese," New York Times, December 21, 1962. Journalism historian David Hallin, in his study of media coverage during the Vietnam War, notes that the "Green Berets in the Central Highlands seemed to be a favorite subject of Halberstam's." Hallin, The "Uncensored War," 222, footnote 53.
} 
a knife, camouflage poncho, and green beret for children to add guerrilla fighting to their repertoire of war play. ${ }^{101}$

Dell Publishing began releasing its Jungle War Stories comic books in 1962. Set in Vietnam and Laos, the stories centered around three American Special Forces "advisors" who fought communist guerrillas wherever they encountered them. ${ }^{102}$ Always outnumbered and frequently betrayed by ostensible allies, the Green Berets defeated their enemies more through clever schemes and ingenuity than by superior firepower. ${ }^{103}$ They gained the trust of villagers and tribesmen by demonstrating their goodwill and purity of motives. In "Operation Mongrel," Captain Duke Larsen befriends Meo tribesmen by showing them an American flag, "the one thing they respect." The tribesmen help the team defeat the attacking enemy rebels of the Pathet Lao and then haul the team's military gear on dog sleds to their final objective. ${ }^{104}$ In another story, set in Vietnam, a group of farmers use tactics taught to them by "a Yankee advisor" to defend their village against "maggots from the North."105 The evident frontier imagery transposed the plains of the American West onto the jungles of Southeast Asia, where Green Berets served as gunslingers for threatened pioneer settlements.

The early film and television appearances of the Green Berets were, for the most part, minor roles. These appearances, however, demonstrate a growing public interest in Special

${ }^{101}$ Sears Christmas Catalog (Chicago, IL: Sears, Roebuck and Co., 1963), 171.

${ }^{102}$ Two of the soldiers are depicted in the comic books wearing the red berets of the South Vietnamese Army Rangers, while the third soldier wore an Australian bush hat. However, the cover art always depicted their berets as green. See Jungle War Stories 3 (Dell Comics, April-June 1963); Jungle War Stories 7 (Dell Comics, April-June 1964); Jungle War Stories 8 (Dell Comics, July-September 1964); and Jungle War Stories 9 (Dell Comics, OctoberDecember 1964). The three main characters trained Vietnamese Rangers in guerrilla warfare. See "Requiem for a Red," Jungle War Stories 1 (Dell Comics, July-September 1962).

${ }^{103}$ In "Surprise Party" Cactus Kane unloaded buckets of ice from a C-130 to frighten off enemy forces who were attacking a village. A similar scheme was used in "Star-Studded Blockbuster" when the team used a film projector to trick attackers into believing they were about to encounter a regiment of defending troops. See "Surprise Party" and "Star-Studded Blockbuster" in Jungle War Stories 8 (Dell Comics, July-September 1964).

104 "Operation Mongrel," Jungle War Stories 3 (Dell Comics, April-June 1963).

105 "War Without Bullets," Jungle War Stories 9 (Dell Comics, October-December 1964). 
Forces and in their missions. In 1962, Surfside 6 featured an episode, "The Green Beret," in which private investigator Dave Thorne was recalled to active duty to help train a Special Forces team-and identify a saboteur at a domestic nuclear installation. After completing the mission, he was presented with an honorary green beret. When his friend asked if she could have it, as it was "kind of cute," he replied, "Are you kidding? After what I went through to get this, just let anybody try and take that away from me." ${ }^{106}$ An episode of the Twilight Zone, "In Praise of Pip," began in Vietnam, when a Green Beret officer brought a wounded soldier into a field hospital after he had been injured during an enemy ambush. When the soldier's father heard the news, he remarked in dismay, “My kid is dying in a place called South Vietnam. There isn't even supposed to be a war going on there, but my son is dying." ${ }^{107}$ While Surfside 6 showcased the Green Berets in their original role as anti-Soviet guerrillas, by the time the Twilight Zone episode aired, the following year, Green Berets and their more expansive mission in Southeast Asia were gaining increasing attention in the media spotlight. ${ }^{108}$

The Green Berets made their appearance on the big screen in 1964 in Seven Days in May, a political thriller about a military coup d'état, adapted from the best-selling book by the same name. ${ }^{109}$ The plot centered around a top-secret military installation guarded and staffed almost exclusively by Green Berets, who were presumably unaware of the machinations of their superiors. The deputy commander of the base-a Green Beret-discovered the plot and risked his

\footnotetext{
${ }^{106}$ Surfside 6, season 2, episode 24, "The Green Beret," directed by Paul Landres, featuring Lee Patterson, aired March 5, 1962, on ABC (Warner Brothers Television).

${ }^{107}$ Twilight Zone, season 5, episode 1, "In Praise of Pip," directed by Joseph M. Newman, written by Rod Serling, aired September 27, 1963, on CBS (CBS Productions).

${ }^{108}$ Rod Serling originally set "In Praise of Pip" in Laos, though a writer later changed the location to Vietnam. See "TV Talkback," Los Angeles Times, November 18, 1984.

${ }^{109}$ For a discussion of Kennedy's support for the film-including granting White House access-and other production details, see Lawrence H. Suid, Guts and Glory: The Making of the American Military Image in Film (Lexington, KY: University Press of Kentucky, 2002), 240-242. The screenplay was written by Rod Serling, who also wrote the Twilight Zone episode "In Praise of Pip."
} 
life to help the president's ally escape the site and report back to the president, preventing the coup. ${ }^{110}$ While the film was not a nuanced depiction of Special Forces, the movie illustrated the ways in which filmmakers already were beginning to use these soldiers to indicate both the unconventional and the heroic. However, there remained a somewhat muddled notion of what these men actually did: were they supermen, superspies, or soldiers of social development? This confusion would persist in media depictions through the decade.

Outside the comic books and movie theaters, the actual U.S. Army Special Forces first deployed to Vietnam in 1957, where they trained conventional South Vietnamese forces in unconventional, offensive warfare. ${ }^{111}$ However, by 1961, their primary mission had shifted to supporting the Civilian Irregular Defense Group (CIDG) program, in which marginalized minority groups were organized and trained as guerrilla fighters. ${ }^{112}$ First envisioned as a defensive program, Special Forces teams moved into remote villages, offering medical care and small aid programs to gain political support of the people. While the implementation varied from village to village, the essential elements were to help construct simple defensive perimeters and equip and train local forces in basic fighting techniques. ${ }^{113}$ The official history of Special Forces in Vietnam referred to the CIDG program as "an amalgamation of many little programs, all of which aimed at the protection of and development of minority groups against insurgency."114

\footnotetext{
${ }^{110}$ In the film, the president says the enemies are not those who plotted against him. Rather, "the enemy is an age, the nuclear age." Seven Days in May, directed by John Frankenheimer, screen play by Rod Serling (Paramount, 1964), 1:35:29 to 1:35:42.

${ }^{111}$ See Shelby L. Stanton, Green Berets at War: U.S. Army Special Forces in Southeast Asia, 1956-1975 (New York: Ivy Books, 1985), 38-40; and Simpson, Inside the Green Berets, 94-95.

112 The CIDG program was initially known by a variety of names, including "village defenders," "area development," and "hamlet militia." See Francis J. Kelly, U.S. Army Special Forces, 1961-1971 (Washington, DC: US Government Printing Office, 1973, 2004), 32.

${ }^{113}$ See Simpson, Inside the Green Berets, 101-103.

${ }^{114}$ Kelly, U.S. Army Special Forces, 33.
} 
The CIDG program was implemented under CIA authority until 1963, when the Military Assistance Command, Vietnam (MACV) assumed control. This handover marked a transition in the program away from defensive hamlets to offensive operations and border surveillance patrols launched from increasingly fortified compounds. ${ }^{115}$ As the program became more firmly established, and the American military presence in South Vietnam grew, Special Forces teams also began implementing larger civic action projects. These included construction of small medical facilities, schools and roads, improving agricultural and livestock yields, and digging wells. ${ }^{116}$ It was this aspect of the Green Berets, what historian Heather Stur calls the "gentle warrior," that helped establish the groundwork of the mythic hero of the Vietnam War. ${ }^{117}$ As the Saturday Evening Post proclaimed, the trademark of Special Forces was not their martial prowess but rather their ability to combine the use of force with "the doing of good works, the bringing of medical care and all the other arts of progress." 118 They were the military embodiment of Kennedy's New Frontier, meeting the communist threat in the jungles of Vietnam and defeating it by winning the "hearts and souls" of the people.

And this media coverage encouraged young men to join the Green Berets. One of those who enlisted was Robert Shippen, who "wanted to get involved," wanted to be "one of Kennedy's youth." He believed that America was in a "sometimes hot war with the communists and that we were a beacon of light for humanity." He saw the conflict in Vietnam as a part of that struggle, that "the Vietnamese Communists were invading our allies in the South," that the

\footnotetext{
${ }^{115}$ See Simpson, Inside the Green Berets, 105; Kelly, U.S. Army Special Forces, 33-34; and Paddock, U.S. Army Special Warfare, 157-158.

${ }^{116}$ See Kelly, U.S. Army Special Forces, 59-63 for a detailed list of civic action projects implemented during this period and the problems the program encountered.

${ }^{117}$ See Heather Marie Stur, Beyond Combat: Women and Gender in the Vietnam War Era (New York: Cambridge University Press, 2011), 4-5 and 142-143 for a broader discussion of the "gentle warrior" as a metaphor for American imperialism.

${ }^{118}$ Kraft, "Hot Weapon in the Cold War," 88.
} 
communists were "really the enemy." 119 Shippen went to an Army recruiting station, saw the posters on the wall, including one of a "Hollywood shot of a Green Beret," who was laying in the woods and holding a rifle--wearing his green beret-and Shippen decided to enlist. ${ }^{120}$ He wanted to try for Special Forces, to "try for the best and see how far" he might get. Shippen trained as a Special Forces medic and deployed to South Vietnam, where he hoped "to save the poor, oppressed people." $" 121$

The media spotlight that shone on the Green Berets in the Kennedy era was due to a combination of efforts by both Special Forces commanders and the president himself. Special Forces command had been attempting to drum up public interest in their organization since as early as 1954, the same year they began accepting direct enlistments into the program. But the Green Berets also profited from a growing curiosity among the American population that was fueled by popular media outlets. This is amply illustrated by the numerous photographs of Special Forces soldiers-their training, gear, and weapons-and the official quotes by senior commanders that appeared regularly in the media's coverage. ${ }^{122}$ These articles began appearing half a decade prior to Kennedy's election and indicate the creation of the Green Beret myth cannot be attributed solely to the president.

Kennedy, however, undeniably was fascinated by these soldiers and his interest went beyond that of mere propaganda. ${ }^{123}$ After the president's assassination, Robert Kennedy

\footnotetext{
${ }^{119}$ Robert Shippen, interview with Richard B. Verrone, May 25-26, August 7, 10-11, 14, September 11, 21-22, and October 6, 2006, transcript, Oral History Project, Vietnam Archive, Texas Tech University, 31-32.

${ }^{120}$ Normally, in such field operations, Green Berets would wear a field cap, not a green beret.

${ }^{121}$ Shippen, interview, 46, 98.

${ }^{122}$ See, for instance, “Army's Green Beret Is Trademark of Special Brand of New Soldier," Escanaba Daily Press, December 14, 1955; Blair, "Toughest Outfit in the Army," Saturday Evening Post, May 12, 1956; and Bem Price, "Fort Bragg's Master Troublemakers," Raleigh News and Observer, June 21, 1959. Some scholars argue Special Forces commanders, particularly Yarborough, "capitalized on Kennedy's interest in irregular warfare" to build up Special Forces funding, missions, and manpower. See Paddock, U.S. Army Special Warfare, 156.

${ }^{123}$ Numerous scholars have examined Kennedy's interest in Special Forces, though most argue he created and used the myth of the Green Berets to bolster support for his counterinsurgency policy in Vietnam. See Gustainis, "John F.
} 
personally requested Green Berets for the president's honor guard, as he "was aware of his brother's particular interest in them."124 The president's widow likewise requested that a platoon of Special Forces soldiers be added to the funeral procession. Ultimately, they not only stood guard over Kennedy's casket in the White House and marched beside it during the procession, but they also flanked the final walkway to his gravesite. ${ }^{125}$ This inclusion of Green Berets in the slain president's memorial services indicates an interest that went beyond simple media manipulation. As historian Steven Watts argues, Kennedy's fascination with Special Forces was reflective of the "broader masculine mystique of the New Frontier."126 The fascination of the American public with the Green Berets, meanwhile, was just beginning.

Kennedy and the Green Berets," 45; Koenig, "The Story of the Green Berets," 65-66; and Tom Engelhardt, The End of Victory Culture: Cold War America and the Disillusioning of a Generation (Amherst, MA: University of Massachusetts Press, 1995), 165-166. For scholars who argue that Kennedy was himself captivated by the Green Berets, see Watts, JFK and the Masculine Mystique, 261; and Eliot A. Cohen, Commandos and Politicians: Elite Military Units in Modern Democracies (Cambridge, MA: Center for International Affairs, 1978), 40-41. Hugh Sidey quoted Kennedy saying of Special Forces: "I like those berets. The Special Forces need something to make them distinctive. My father even wears one now." Sidey, John F. Kennedy, 205.

${ }^{124}$ B.C. Mossman and M. W. Stark, The Last Salute: Civil and Military Funerals, 1921-1969 (Washington, DC: US Government Printing Office, 1991), 190-191. Robert Kennedy visited Fort Bragg in 1965 to dedicate new headquarters and academic buildings in his brother's honor. He told those assembled for the ceremony at the Center for Special Warfare that the late president "had a special place in his heart" for Special Forces, that they were not soldiers who "destroy people, but instead destroy ignorance." See “A Kennedy Visits Army JFK Center," San Antonio Express, May 30, 1965.

${ }^{125}$ Mossman and Stark, Last Salute, 200, 210. One of the soldiers who formed part of the honor cordon at Arlington laid his green beret on the ground beside Kennedy's grave after the coffin had been lowered into the ground. The soldier, Sergeant Major Francis J. Ruddy, claimed the act was "completely spontaneous, not premeditated-it was pretty much a reflex." According to the New York Times, by the next morning, "caps from the four other military services were also there." For several years thereafter, the military caps were the only permanent mementos at Kennedy's grave. See Nan Robertson, "Faded Military Caps on Grave of Kennedy Will Be Replaced," New York Times, January 15, 1965. The original green beret laid by Sgt. Maj. Ruddy is on permanent display at the John F. Kennedy Presidential Library and Museum.

${ }^{126}$ Watts, JFK and the Masculine Mystique, 261. Special Forces likewise admired President Kennedy, renaming the Special Warfare Center and School at Fort Bragg in his honor. A 1965 New York Times article claimed that "all Special Forces troops" speak "well of President John Kennedy." See Jack Langguth, "They Are Not Jolly in the Foxholes," New York Times, May 9, 1965. 


\section{The Enshrinement of the Myth, 1965- 1968}

As conventional American ground combat troops began to deploy to Vietnam in increasing numbers during the spring and summer of 1965, media coverage of Special Forces remained strong. Green Berets were featured on the covers of National Geographic and the Saturday Evening Post in 1965 and the New York Times continued to highlight the accomplishments of various Special Forces teams throughout Vietnam. ${ }^{127}$ While civic action projects and language skills were still frequently mentioned, the battlefield exploits of Special Forces soldiers became a more common subject for writers. With more and more combat engagements between Americans and Vietnamese communists, this should not come as a surprise. The Saturday Evening Post, for instance, told the "gripping story of how twelve heroic Americans defended one tiny outpost of freedom against a major Viet Cong attack." 128 The article included a picture of President Lyndon Johnson awarding the Congressional Medal of Honor to the Special Forces captain, Roger Donlon, who commanded the team. ${ }^{129}$

But Green Berets exhibited more than just conventional battlefield heroics, as a profile of Captain Vernon Gillespie in National Geographic demonstrated. The article portrayed the "superbly trained and superbly disciplined" soldiers of a Special Forces team whose "raw

\footnotetext{
${ }^{127}$ For example, see Howard Sochurek, "Americans in Action in Vietnam," National Geographic, January, 1965; Roger Donlon and Warren Rogers, "The Battle for Nam Dong," Saturday Evening Post, October 23, 1965; Jack Langguth, "Special Forces Team Watches Cambodia Border," New York Times, January 28, 1965; and Hanson W. Baldwin, "Scarred Stronghold at Pleime Is Fortified Anew," New York Times, December 8, 1965.

${ }^{128}$ Donlon, "The Battle for Nam Dong," 38.

${ }^{129}$ Despite publicity that highlighted the language abilities of Special Forces, few who served in Vietnam spoke Vietnamese or any of the Montagnard languages, though some soldiers did speak French. Donlon, like most, spoke only a few words of Vietnamese, which hampered his efforts during the attack. See Donlon, "The Battle for Nam Dong," 41.
} 
heroism" and "awesome display of personal courage" halted a revolt of mountain tribesmen. ${ }^{130}$

While his bravery was undeniable, Gillespie had ultimately won the day through his keen

understanding of the "mountain people" whom he had "been sent to guide and protect."131 By donning tribal garb and participating in a ceremony that bound him to other village fightersactions that a "lesser man" would not "have realized the necessity of, or taken the time for"Gillespie had averted a disaster. ${ }^{132}$

Special Forces were showing Americans that in Vietnam, the lessons of The Ugly American had been taken to heart. Soldiers wearing green berets lived among the people, eating the same food, fighting the same battles, and laboring to help local tribes on the path to freedom and development. And this contest over local political loyalties mattered. A large majority of the U.S. public in 1965 believed that South Vietnam would be lost to the communists without American support. ${ }^{133}$ The adulatory media coverage of the Green Berets allowed one to feel not only that something was being done to prevent communist aggression, but that it was being done in the right way-the modern, enlightened way.

The publication of The Green Berets, in May 1965, rocketed Special Forces to new heights of popularity. Written by Robin Moore, the best-selling novel cemented the term "green beret" in the public consciousness for decades to come. ${ }^{134}$ Though Moore's work was published

${ }^{130}$ Sochurek, "Americans in Action in Vietnam," 51, 56, 64.

${ }^{131}$ Gillespie, despite his "understanding of the mountain people," was reliant upon an interpreter to communicate with his Montagnard troops. See Sochurek, "Americans in Action in Vietnam," 53.

${ }^{132}$ Ibid., 46, 51.

${ }^{133}$ William M. Hammond, Public Affairs: The Military and the Media, 1962-1968 (Washington, DC: US Government Printing Office, 1988), 181.

${ }^{134}$ Robin Moore is the pen name of Robert Lowell Moore, Jr. While it's not entirely clear how Moore was allowed to train with Special Forces, Moore claimed in The Green Berets that he met Vice President Johnson, and his military aide, in Jamaica in 1962 and told him of his interest in writing a book on Special Forces. Moore had previously written a book about Castro and guerrilla warfare in the Caribbean, The Devil to Pay. According to Moore's wife, he used his father's position as co-founder of the Sheraton Hotel Corporation to sneak his novel into Johnson's hotel room. An alternate version is that Moore spoke to Johnson's military aide. In yet another version of the story, Moore said he used his relationship with Harvard classmate Robert F. Kennedy to obtain presidential approval for his project. Regardless of the reason, Moore was given permission to attend the Special Forces officer's 
as fiction, the first sentence of the novel claimed otherwise: "The Green Berets is a book of truth." ${ }^{135}$ Comprising nine stories, each of which purported to tell "a different facet of Special Forces action," there was no shortage of death, torture, sex, and intrigue in Moore's writing. Leaving the "civic action portion of Special Forces operations" to another writer, one comfortable with simple factual reporting, Moore boasted that he "saw too many things," and "assisted in too much imaginative circumvention of constricting ground rules" to be bound by the constraints of nonfiction. ${ }^{136}$

The national media outlets who reviewed The Green Berets did so only after it was well established on the best-seller list; their reviews were almost universally censorious. The Chicago Tribune said Moore should have forgone "claims to facts" and stuck to spinning "yarns." Their review noted that the villains in The Green Berets are "Americans who abide by regulations, most Vietnamese officers, and all American officers not in the special forces." ${ }^{\prime 37}$ The New York Times thought Moore's "vividly unpleasant" stories demonstrated "an addiction to cruelty that makes Vietnamese and Americans in the jungle kin." ${ }^{138}$ A review in Time wondered that "Moore's Special Forces men seem to spend little time on the humdrum public health and education programs and antiguerrilla training that are among the SF's major responsibilities."139 Indeed, the soldiers of Moore's Green Berets paid but lip service to the ideals of Kennedy's New Frontier. Moore noted in passing that the Special Forces medical program was "winning over" whole villages, but much more space was devoted to detailing prisoner

course at Fort Bragg, after which he traveled to Vietnam, where he was embedded with various teams for approximately six months. See Moore, Green Berets, 11-17; J.M. Lawrence, "Robin Moore, 82, Author of 'French Connection,' 'Green Berets,"' Boston Globe, February 24, 2008; and Robert N. Strassfeld, "Vietnam War on Trial: The Court Martial of Dr. Howard B. Levy," Wisconsin Law Review 1994, no. 4 (1994): 906.

${ }^{135}$ Robin Moore, The Green Berets (New York: Crown Publishers, 1965), 11.

${ }^{136}$ Ibid., 11-12.

${ }^{137}$ Arthur Veysey, "Unorthodox Warriors," Chicago Tribune, July 4, 1965.

${ }^{138}$ Gordon Harrison, "Dilemmas in Vietnam," New York Times, July 11, 1965.

139 “One Man's War,” Time, June 25, 1965, 109. 
interrogation techniques, the cut-off date for visiting prostitutes before returning home to wives and girlfriends, and the value of assassinating political officials. ${ }^{140}$ Moore also wrote that "Special Forces men are entirely conversant with tribal mores and superstitions," though in two of his stories, this translated into graciously accepting young tribeswomen into bed. ${ }^{141}$ An examination of the media coverage of The Green Berets reveals a divergence of opinion in the reviews between the national and local media. While the national media dismissed Moore's work as both insulting and shocking, smaller media outlets were largely admiring. A reviewer in Texas said Moore's stories are "reminiscent of the best of Ernie Pyle" with an "added dash of James Michener color and James Bond excitement."142 "Most Important Book of 1965?" was the question asked in the Tennessean, in which the reviewer stated, "for the first time the war in Viet-Nam takes shape in dramatic and explosive form that can be grasped by any reader of any age." 143

Even those reviewers in lesser markets who found the literary value of Moore's book wanting still recommended it and lauded the Special Forces as "the first successful answer short of total nuclear annihilation we have found to the Moscow-Peiking cancer."144 Another reviewer,

\footnotetext{
${ }^{140}$ Moore, Green Berets, 321. See Moore's story “A Green Beret-All the Way” for torture of prisoners; “The Immortal Sergeant Hanks" for sexual activity cut-off dates; and "Hit 'Em Where They Live" for political assassinations.

${ }^{141}$ Moore, Green Berets, 257. In the chapter "Hit 'Em Where They Live," Captain Smith went to bed with the chief's daughter, saying it "would be impolite and bad form for him to have refused." Moore, Green Berets, 300. In "Home to Nanette," Bernard Arklin selected a 15-year-old girl, Nanette, as a wife from among three who were offered. Though he originally resolved to keep their relationship platonic, by the sixth night he had consummated the marriage. Not only was Nanette "thoroughly pleased and satisfied," but the entire village began working with improved efficiency and purpose. When Arklin left the village to return home to his American wife and children, he was careful to note that Nanette "had a lot to do" with his success on the mission. Moore, Green Berets, 185, 231.

${ }^{142}$ Leonard Sanders, "Books Show Kind of War in Viet Nam," Fort Worth Star-Telegram, July 18, 1965. A review in Time said Moore's "sly commingling of fact and fiction becomes in the end an insult to the intelligence of the reader." See "One Man's War," Time, June 25, 1965, 110. The Chicago Tribune reviewer wrote that Moore's book was "full of shocks," and could be "a strong weapon for foes of American actions in Viet Nam." See Arthur Veysey, "Unorthodox Warriors," Chicago Tribune, July 4, 1965.

${ }^{143}$ G. Frank Burns, “Most Important Book of 1965?” Tennessean, July 11, 1965.

${ }^{144}$ John R. Breitlow, "These New Elite Warriors Are Practicing an Old Trade," Winona Daily News, August 22, 1965.
} 
this one in Fort Lauderdale, described Special Forces as "spectacularly non-ugly Americans."145

Without question, there was a sense in these narratives that Vietnam was a different kind of war, and as Americans struggled to make sense of it, they praised the Green Berets as the men who had mastered this new, dirty style of modern warfare. One reviewer described the war, as fought by the men of The Green Berets, as cold-blooded, devious, and intimate. ${ }^{146}$ In a review that dismissed Moore's "hero-worship" of the Green Berets as "straight off the Warner Bros." grade B movie lot, a California reviewer nevertheless found the book "fascinating," because "that's the kind of war it really is." ${ }^{147}$ A librarian in New Mexico noted much the same. Warning readers Moore's stories "will shock the prudish and nauseate the squeamish," she nevertheless believed "they picture war as it is now being fought in the jungles of Asia and jungle warfare is never pretty." 148

There were additional elements to the coverage as well that gave the book a frisson of the forbidden. One of these was the charge by military officials that The Green Berets contained sensitive information. ${ }^{149}$ The New York Times published an article detailing the controversy, noting that the Pentagon, CIA, and other government agencies had "taken exception to the book." 150 The government's objections centered on the novel's stories of cross-border operations, torture, and the contempt with which Moore's Americans treated their Vietnamese

145 “The Green Berets: Special Forces Story,” Fort Lauderdale News, August 15, 1965.

${ }^{146}$ Leonard Sanders, "Books Show Kind of War in Viet Nam," Fort Worth Star-Telegram, July 18, 1965. In this same article, Sanders wrote, "The explanation that the war in Viet Nam is a "new kind of war' has become a cliché." ${ }^{147}$ Richard C. Wald, "Our Tempest in the Rice Bowl," San Francisco Examiner, November 7, 1965.

${ }^{148}$ Ruth H. Feas, "Book Review: The Green Berets," Rio Grande Sun, December 16, 1965.

${ }^{149}$ Moore said he had attempted to submit his manuscript to the Pentagon for clearance, but had been told they didn't review works of fiction. The Assistant Secretary of Defense for Public Affairs, Arthur Sylvester, claimed he never saw a manuscript, that the book was already in print when his office first saw it. Sylvester said Moore had "refused to be bound by his word" and that certain information he had received was meant to be purely on an "off the record" basis. See Arthur Sylvester, interview with Lawrence H. Suid, December 23, 1974, transcript, JFKOHAUS-02, John F. Kennedy Presidential Library and Museum. For Moore's account of events, see "One Man's War," Time, June 25, 1965, 109.

${ }^{150}$ Hanson W. Baldwin, "Book on U.S. Forces in Vietnam Stirs Army Ire,” New York Times, May 29, 1965. 
partners. The San Francisco Examiner covered the controversy in "Pentagon Brass vs. Green Berets," noting that while The Green Berets was mostly ignored in "major review media," the book was in its sixth printing two months after its release and was doing "swingingly in San Francisco.” The article, and many like it published around the nation, claimed the Pentagon's objections to the novel stemmed not from national security concerns but from the hatred that "conventional military minds" had for "the bizarre, the unconventional, the outside-of-channels operation" of Special Forces. ${ }^{151}$ The military's concerns over Moore's novel merely fanned the flames of the public's interest in the Green Berets-both the real life soldiers and their fictional counterparts. And this depiction of Green Berets as rule breakers who rose above such petty notions as international boundaries and conventional rules of engagement, and who thrived despite the best efforts of the strait-laced military brass, was intoxicating to many Americans.

Robin Moore, one of the people most responsible for establishing the myth of the Green Berets, was also one of its first victims. Because he admired them and thought of himself as one of them, he could not imagine that they might fail. In his mind, if the Green Berets had been allowed to operate without constraints, without being "hamstrung by politicians," they would soon have had "Uncle Ho" at the bargaining table. ${ }^{152}$ As one former Special Forces noncommissioned officer wrote of Moore's novel, the author "painted a picture of Special Forces

\footnotetext{
${ }^{151}$ Donald Stanley, "Pentagon Brass vs. Green Berets," San Francisco Examiner, July 25, 1965. For other reviews that mention the military's objections to Moore's novel, see "One Man's War," Time, June 25, 1965, 110; and John R. Breitlow, "These New Elite Warriors Are Practicing an Old Trade," Winona Daily News, August 22, 1965.

${ }^{152}$ Robin Moore, The Green Berets (New York: Skyhorse, 1965, 2015), 429. This was a familiar refrain among U.S. military officers after Saigon fell in 1975. As one example, see U.S. Grant Sharp, Strategy for Defeat: Vietnam in Retrospect (San Rafael, CA: Presidio Press, 1978). Sharp was the Commander-in-Chief, Pacific Command during the war.
} 
as they might once have been and as they would like to be-but not as they are." In other words, Moore helped perpetuate "a Special Forces self-created myth."153

Moore's daughter also spoke of the myth's allure, noting of her father that the Special Forces was "the thing he kept returning to." 154 This was literal as well as figurative, for when Moore retired, he bought a home near Fort Campbell, Kentucky, to be near the men of $5^{\text {th }}$ Special Forces Group. Saying “this is home,” Moore helped fund a "clubhouse” for Green Berets, whose members considered him their "icon." They kept a bottle of scotch ready at all times for him, their version of "Kennedy's eternal flame." Moore lived the rest of his life, as he had intended, "in the embrace" of his Special Forces brethren. ${ }^{155}$ When he died, Major General Gary Harrell, deputy commanding general of Special Operations Command, said Moore’s "writings on Special Forces are textbooks for our modern unconventional warriors; they were both educational and inspirational and introduced the world to the Green Berets." 156 That the public might have considered The Green Berets a work of fact is disturbing enough, but for military commanders in the twenty-first century to call it "inspirational" is downright chilling.

Moore's role as mythmaker equally can be discerned in modern day scholarship on the Special Forces and the American war in Vietnam, both of which often cite self-aggrandizing claims of the novelist as unchallenged fact. One of these is that Moore had a security clearance which the Army revoked in its displeasure over The Green Berets. However, evidence suggests

\footnotetext{
${ }^{153}$ Don Duncan, "Books: The Army's Longest Recruiting Pamphlet," Ramparts 4, no. 10 (February 1966): 66. An article on Robin Moore that was published two years prior to his death said The Green Berets "fueled a myth." See Tim Ghianni, "Fighting Soldiers, Tender Brothers," Tennessean, September 11, 2006.

${ }^{154}$ J.M. Lawrence, "Robin Moore, 82, Author of 'French Connection,' 'Green Berets,"” Boston Globe, February 24, 2008. Moore also later wrote several books about Special Forces in the Global War on Terror: The Hunt for Bin Laden (2003) and Hunting Down Saddam (2004).

${ }^{155}$ The bottle of scotch had special significance, as Moore had purchased it for $\$ 10,000$ in a fund-raiser for the clubhouse. Tim Ghianni, "Fighting Soldiers, Tender Brothers," Tennessean, September 11, 2006.

${ }^{156}$ Henry Cuningham, "Robin Moore, Author of 'The Green Berets,' Dies," Fayetteville Observer, February 22, 2008.
} 
that Moore may never have had any such clearance and that he only ever held press

accreditation. ${ }^{157}$ Another oft-cited assertion is that the success of Moore's book allowed the

Selective Service to "suspend draft calls during the first four months of 1966." "158 While some

number of enlistments surely were inspired by Moore's adventure-filled tales of the Special

Forces, there is no evidence that they were of sufficient quantity to affect induction rates. ${ }^{159}$

Thus, even today, scholars who study the Special Forces and the role of Moore's novel are

unwittingly feeding the myth themselves.

While it is unclear who exactly authorized Moore to train with Special Forces, or to tag

along with them in Vietnam, it ultimately was a brilliant publicity move. The exact number of

enlistments Moore's novel inspired are impossible to ascertain, but its cultural impact went

\footnotetext{
${ }^{157}$ As recently as 2017, this claim was cited in an academic publication with no supporting evidence, other than Moore's word. See Roger Lander, "Barry Sadler and 'The Ballad of the Green Berets," in The Vietnam War in Popular Culture: The Influence of America's Most Controversial War on Everyday Life, vol. 1, During the War, ed. Ron Milam (Santa Barbara: Praeger, 2017), 157. However, Arthur Sylvester, the Assistant Secretary of Defense for Public Affairs, claimed in an interview that Moore "wasn't cleared for secret information at any time, for anything." Sylvester said it was likely Moore had confused his press accreditation with a security clearance. See Sylvester, interview, 2. Moore's claims can be found in the introduction to the 1999 edition of his book. See Robin Moore, The Green Berets (New York: Skyhorse, 2015), xi-xii. While the full truth may never be known, by not citing both accounts of the story, Moore is portrayed as yet another victim of the conventional military's distaste for Special Forces.

${ }^{158}$ The first academic source for Moore's claim regarding the draft is found in Hellmann, American Myth and the Legacy of Vietnam, 53. Others who cite Hellmann include Koenig, "The Story of the Green Berets," 72; and Gustainis, "John F. Kennedy and the Green Berets," 50.

${ }^{159}$ Enlistment numbers varied considerably in the first year of the troop buildup in Vietnam. The January 1966 draft call was cut by 1,000 men, February's by 5,000, and March's by 10,300 men. However, April's enlistments were down, leading the Defense Department to raise draft calls by a total of 9,500 men in May and June. See Bob Horton, "May, June Draft Quotas Raised Without Notice," Petaluma Argus-Courier, June 4, 1966. Analysts believed the high numbers of enlistees in the early part of 1966 were due to a combination of lowered admission standards and men who were draft motivated to enlist in the service of their choice. See "Enlistments Near Record Set Last Fall," Baltimore Sun, February 27, 1966. While these are national numbers, some states did have sufficient enlistments to be able to cancel their draft quotas in certain counties. For instance, Comanche County, Oklahoma, had enough enlistments in February 1966 to cancel the March draft call. See Virgil Gaither, "Rush of Recruits Halts Draft Calls in County," Lawton Constitution, February 25, 1966. It is possible that Moore saw a local report of a draft cancellation and attributed this to his novel's success. However, when enlistments rose, they rose for all services, not just for the Army. For example, the Army saw an increase in its enlistment numbers in January 1966 that was 118 percent above January 1965. For the same period, the Marines saw their numbers rise by 165 percent. It therefore seems unlikely that the enlistment rise was due mainly to Moore's novel, especially as January is "traditionally the top enlistment month." See "Enlistments Near Record Set Last Fall,” Baltimore Sun, February 27, 1966.
} 
beyond sheer recruitment numbers. ${ }^{160}$ Apart from a comic strip and a hit movie that were directly tied to The Green Berets, numerous commercial spin-off products appeared in the years that followed. Multiple Green Beret-inspired novels appeared on sales racks, both for men and women, depicting the romance of the warfare in Southeast Asia and the Special Forces soldiers who fought there.

The Women of the Green Berets were "heartsick to help the heroes they loved" and had to fight "their own shattered emotions first." The novel contained many scenes of battle, though unlike Moore's Green Berets, these soldiers were proud of the civic action projects they were implementing and contemptuous of reporters who ignored this good work and instead searched for stories of combat heroics. ${ }^{161}$ Others novels were much the same, with various mixtures of sexual intrigue, unreliable allies, and battlefield redemption. ${ }^{162}$ While the novels may well have been attempts to capitalize on a trend, they also reveal a romantic notion of militarized masculinity personified in an idealized soldier, one whom women gladly bedded and men longed to be.

But these novels were merely part of a much larger cultural trend, one which gained momentum with the release of the hit single "The Ballad of the Green Berets." Written by Barry Sadler, a Special Forces sergeant, this chart-topping song of 1966 was not the usual military fare.

\footnotetext{
${ }^{160}$ One has only to search through the Vietnam Archive at Texas Tech University to find veterans who mention The Green Berets. One such veteran is James McLeroy, who liked what he read in The Green Berets and said, "That's for me." He joined in October 1965, finished Officer Candidate School, Airborne school, Ranger school, and Special Forces training, and was sent to Vietnam in 1967 as a second lieutenant. Though McLeroy was draft exempt, he decided to join because he was "idealistic" and militantly "anti-communist." See James McLeroy, interview with Stephen Maxner, September 18 and October 3, 2000, transcript, Oral History Project, Vietnam Archive, Texas Tech University, 3, 15. Even decades after the Vietnam War, Special Forces soldiers cite The Green Berets as motivation for enlisting. A 1997 study on Special Forces mentions a soldier who, after reading Moore's novel in high school, decided that he "would become a Special Forces soldier." See Anna Simons, The Company They Keep: Life Inside the U.S. Army Special Forces (New York: Free Press, 1997), 182.

${ }^{161}$ Rand Michaels, Women of the Green Berets (New York: Lancer Books, 1967).

${ }^{162}$ Examples of fictional accounts of Special Forces include Jacob McCroskey, Operation Axe-Handle (New York: Lancer Books, 1967); Peter Derrig, The Pride of the Green Berets (New York: Paperback Library, 1966); and Daniel Ford, Incident at Muc Wa (New York: DoubleDay, 1967).
} 
Less a glorification of combat and more an ode to men who die "for those oppressed," the song praised the courage, training, and exclusivity of "America's best." The song ended not with a ringing victory, but with a soldier's death, and his wish that his son one day test to "win the green beret." 163 Robin Moore, in exchange for a half interest in Sadler's song, wrote a few of the lyrics and agreed to help promote the song. ${ }^{164}$ But the tie-ins didn't end there. Sadler was featured as the Green Beret on the paperback edition of Moore's novel and during Moore's book-signings, he played Sadler's record. ${ }^{165}$ The song was a run-away success, described variously as "the single most popular song of 1966" and "RCA's best selling single in history." 166 In its advertising, RCA pushed Sadler's song as "a hot new single with a ready-made market of millions who have read the best-selling book, The Green Berets." ${ }^{167}$ RCA also sent radio stations, media outlets, and vendors a promotional kit that included Sadler's biography, pictures, and a Special Forces brochure. ${ }^{168}$

The U.S. Army was more than happy to capitalize on the publicity of Sadler's song, reassigning him to the Fort Bragg Public Information Office, whence he toured the country as a "flesh-and-blood singing recruiting poster." 169 For the next eighteen months, Sadler was kept busy with public appearances, playing the part of a media-manufactured hero, as he later characterized it. Sadler, however, didn't see himself as a hero, was tired of being a "figurehead,"

\footnotetext{
${ }^{163}$ Barry Sadler, "The Ballad of the Green Berets," lyrics by Barry Sadler and Robin Moore, recorded December 1965, RCA Victor.

${ }^{164}$ Barry Sadler and Tom Mahoney, I'm a Lucky One (New York: Macmillan, 1967), 173.

${ }^{165}$ See Jack Rice, "The Man Who Wrote 'The Green Berets,"” St. Louis Post-Dispatch, December 9, 1965. In media interviews, such as the one cited, Moore claimed he had written all of the lyrics to Sadler's song.

${ }^{166}$ Tad Tuleja, “'America's Best': Cultural Poaching on 'Ballad of the Green Berets,"” in Warrior Ways: Explorations in Modern Military Folklore, eds. Eric A. Eliason and Tad Tuleja (Logan, UT: Utah State University Press, 2012), 249; and R. Serge Denisoff, "Fighting Prophecy with Napalm: 'The Ballad of The Green Berets,"” Journal of American Culture 13, no. 1 (January 1990): 89.

${ }^{167}$ See Billboard, January 22, 1966, 2.

168 "RCA Dressing Up 'Berets,"” Billboard, January 22, 1966, 4.

169 “Tin Pan Alley: No Time for Sergeanting," Time, April 15, 1966, 85.
} 
and longed to return to his job as a Special Forces medic. He described the Vietnam War as "a good little war. It was like everything you'd ever read in books, living with savages with their teeth filed down to the bone, living on the edge, it was just a tremendous experience." 170 When the Army refused to allow him to rejoin his unit, Sadler left the Army, which he said was like "being kicked out of your own house by your father." The military had been the only place he "felt really comfortable" and-fifteen years after his honorable discharge-Sadler said he was "not comfortable at all now" and probably never would be. ${ }^{171}$

Like The Green Berets, Sadler's song also inspired young men to join Special Forces. One of these young volunteers, Robert Kreger, said he heard the "Ballad of the Green Berets" on his college PA system and made a bet with a friend as to "who was tougher," who could become a Green Beret faster. ${ }^{172}$ Kreger said he quit school that day, and went off in his own "little fantasy world," to prove himself manly, both in the eyes of his friends and of his father. While he said he probably would have found some other "quest" if it hadn't have been the Green Berets, he admitted "the fact that at that moment at that place there was that song playing and the heroism and the machoism involved in that song and the notion of a hundred men trying to make it but only three" succeeding, was what inspired him to show that he could do something exceptional. ${ }^{173}$ He never gave up on the idea that he could be in the Green Berets and pursued

\footnotetext{
${ }^{170}$ Billy Cox, “The Ballad of Barry Sadler,” Florida Today, July 5, 1983.

${ }^{171}$ Sadler's life after the military was a series of strange and violent events. He was arrested in 1978 for killing a man in Nashville and Sadler himself was shot in Guatemala City in 1988. He died in Nashville in 1989. For more information on Sadler's life, see Marc Leepson, Ballad of the Green Beret: The Life and Wars of Staff Sergeant Barry Sadler (Guilford, CT: Stackpole Books, 2017). Sadler also helped write a book, I'm a Lucky One, about his life and Special Forces in 1967, though it is not nearly as detailed and informative as Leepson's.

${ }^{172}$ Robert Kreger, interview with Laura Calkins, October 28, November 11, December 9, 2005 and February 9 , 14, 16, 21, March 7, 28, 2006, transcript, Oral History Project, Vietnam Archive, Texas Tech University, 7. Popular culture depictions of the Green Berets were virtually the only pro-military media of the era that had any mass appeal. See Amy Rutenberg, Rough Draft: Cold War Military Manpower Policy and the Origins of Vietnam-Era Draft Resistance (Ithaca: Cornell University Press, 2019), 161.

${ }^{173}$ Kreger, interview, 9-10. The lyrics that Kreger was responding to were from the second verse: "Silver wings upon their chest, these are men, America's best, one hundred men will test today, but only three win the green beret."
} 
that goal by attending advanced infantry training and Officer Candidate School (OCS). After OCS, he went to Fort Bragg, which he described as "a Muslim going to Mecca on the Haj." To see all the "physically fit strapping men walking around wearing their green berets" well it just “gets you excited!” By the time Kreger graduated from training, he thought "bullets would bounce right off' his chest. ${ }^{174}$

By the fall of 1966, popular culture was saturated with all things Green Beret. The retail chain Grants ran an advertisement asking children what their favorite Halloween costume was. Green Beret was listed above Zorro and the Munsters, right under Superman. ${ }^{175}$ A newspaper in Michigan ran an article that declared the trend in toys was "shifting to jungle warfare," and "zooming to the front are GI Joe and Green Beret dolls." Parents could rest easy, knowing that "Pentagon experts served as advisors to the manufacturers." Marx produced a Green Beret set that came with doll, hat, guns, and two cap-firing grenades. ${ }^{176}$ Hasbro sold a Sears-exclusive G.I. Joe Green Beret jungle outpost set, complete with two dolls, shell-firing bazooka, machine gun, grenades, camouflaged netting, and other accessories. ${ }^{177}$ A machine gun outpost set was also available.

If children joined the G.I. Joe club, they could send away for a record that told the story of two young boys, Andy and George, who visit their friend Colonel Pat Lawrence to find out

\footnotetext{
${ }^{174}$ Kreger, interview, 13, 28, 30.

175 See Grants' advertisement, Philadelphia Daily News, October 27, 1966, page 21.

${ }^{176}$ Neil Hunter, “Jungle Warfare Sparks Yule Toys," Lansing State Journal, November 22, 1966.

${ }^{177}$ Sears Christmas Catalog (Minneapolis, MN: Sears, Roebuck and Co., 1966), 511. A separate "Green Beret Outfit," including weapons, was advertised on page 512. Vintage G.I. Joe collectors consider the Green Beret "the most popular of all the original G.I. Joe uniform sets." For pictures of the G.I. Joe toys and an interesting video that includes a reenactment of "The Ballad of the Green Berets" using G.I. Joe action figures, see https:/www.youtube.com/watch?v=vZzrRTwrus8. A related web site contains a plethora of G.I. Joe information: www.3djoes.com.
} 
what it takes to become a Green Beret. ${ }^{178}$ Lawrence tells them the unit's history and explains their training: "every Green Beret has to be an expert at judo, karate, boxing, wrestling, and their own special brand of hand-to-hand combat." Lawrence then shares the story of the battle of Nam Dong and the heroics of Captain Roger Donlon, after which Andy says, "Gee Colonel, those Green Berets are terrific, that's why I wanna be a Green Beret when I grow up!" ${ }^{179}$ The album ends with a stirring rendition of "The Ballad of the Green Berets." The final verses of the song, in which a dying soldier requests that his son put silver wings on his chest and test to win the green beret, took on new significance when played on a children's album. As the war in Vietnam dragged on and casualties continued to mount, G.I. Joe would move away from this symbolic language of warfare and transform into more of a general action hero. But in these early years, he was all man and he was a Green Beret. ${ }^{180}$

Action figures-boys did not play with "dolls"-were merely the beginning, however, as retailers were determined to exploit the public's interest in the Green Berets to whatever extent they could. There were Green Beret-themed gumball machine toys which, for ten cents, gave kids pin-on colonel's rank or a plastic ring that held a small green beret. There was a U.S. Special Forces Green Beret target set, which came with metal targets, printed with images of soldiers in green berets in the thick of combat, and a dart gun. M \& W Products made a green beret that was sized for children, so they could pretend to be one of the "elite corps of the U.S. Armed Forces." While children had been playing war for decades, the Green Berets made it possible to visualize oneself as an elite soldier, one who had mastered all manners of weapons

\footnotetext{
${ }^{178}$ For a short history on the development of G.I. Joe, see Engelhardt, The End of Victory Culture, 175-180. This history is also available on Netflix. See The Toys That Made Us, season 1, episode 4, "G.I. Joe," created by Brian Volk-Weiss, first available to stream on December 22, 2017, Netflix.

${ }^{179}$ Colonel Lawrence refers to the green beret as "jaunty" at least three times on the record. See "The Story of the Green Beret," GI Joe: Stories of Patriotic Americans, Hanna-Barbera Records, 1966, catalogue number HL 2057. ${ }^{180}$ See Hugh Davis, "Million Dollar Man Proves Popular Toy," Spokane Chronicle, September 27, 1975; and Engelhardt, The End of Victory Culture, 177.
} 
and means of killing. ${ }^{181}$ To pretend to be one of Kennedy's chosen soldiers would give one the strength of ten anonymous infantry troops.

The Philadelphia Chewing Gum Corporation sold Green Beret trading cards for five cents a pack, which were based upon the "J.F.K. Special Forces Center" at Fort Bragg. The set consisted of 66 cards, plus a checklist, each with a U.S. Army photo of Special Forces training and gear. There were Green Berets on skis, paddling a boat, rappelling, practicing martial arts, taking down a sentry with a knife to the neck, and holding a giant snake. Once a child had purchased the entire set, they could assemble an image from the reverse side of the cards. With the caption, "Men of the Green Berets," this illustration featured a portrait of a handsome, lightskinned beret-clad soldier in the foreground and various scenes of action in the background: a night-time parachute jump, a scuba-diver rising from the water-knife at the ready-and a helicopter dropping three Green Berets into action, guns blazing. For those kids who took the time to read the cards' captions, they could rest assured that this "modern swamp fox" was no dummy, a Green Beret "uses his brains."

The Green Berets also began making more frequent appearances in comic strips and comic books. Robin Moore's syndicated strip, Tales of the Green Beret, ran for a short time, though it never achieved the level of success of his novel on the Special Forces had. ${ }^{183}$ Unlike Moore's strip, most comic books on the Green Berets that were published in this period were rather innocent depictions of what was happening in Vietnam. Like Moore's work had done, they oversold the abilities and expertise of the Green Berets, but they did not glorify killing in the

\footnotetext{
${ }^{181}$ For a discussion of war play and American identity, see Engelhardt, The End of Victory Culture, 82-86.

182 "Swamp Fox" was a reference to Francis Marion, a farmer who used guerrilla tactics against the British during the American Revolutionary War. See John Oller, The Swamp Fox: How Francis Marion Saved the American Revolution (New York: Da Capo Press, 2016). Walt Disney Presents produced a series called "The Swamp Fox," that debuted in 1959 and ran for eight episodes.

${ }^{183}$ See Bradford W. Wright, Comic Book Nation: The Transformation of Youth Culture in America (Baltimore: Johns Hopkins University Press, 2001), 193.
} 
same way The Green Berets had. Instead, they hewed closer to the Kennedy-era vision of Special Forces as enlightened bestowers of development and freedom.

DC entered the fray by adding "Capt. Hunter" to their Our Fighting Forces comic.

Hunter was a Green Beret whose twin brother had been shot down over enemy territory and was missing in action. Though Hunter was a civilian who quit the Army to go search for his brother in the company of a lovely "Oriental kewpie doll," he continued to wear his beret throughout the series. ${ }^{184}$ The comic does not deal with Special Forces missions and was DC's attempt to keep things, in the words of the editor, "as real as tomorrow's papers." ${ }^{185}$ However, these comics mirrored the vague ideas that the American public held of the American war in Vietnam as a "savage war raging without quarter," one that was "riddling the rules." 186

Our Fighting Forces notwithstanding, it was mainly smaller comic book publishers who took on the Vietnam War. ${ }^{187}$ Tower Comics published stories of the Green Berets in Fight the Enemy. Described as a "super soldier" who was trained to be both a "dynamic fighting force" and a "true crusader of justice and defender of democracy," the Special Forces trooper helped "poor unfortunates who are caught in the path of destruction and hunger." 188 In one headscratching story, the Green Berets took a troublesome draftee soldier named Davis out on patrol. Davis complained, saying he didn't "want any part of this war." He snuck away from the patrol, thinking he might be able to "make a deal with the Cong." However, when Davis saw the violence the Viet Cong wrought on a small village, he attacked them, declaring that "I didn't ask for this war, but after seeing you butchers at work, that did it, someone has to stop your kind!"

\footnotetext{
184 "Death Also Stalks the Hunter," Our Fighting Forces 100 (DC Comics, May 1966).

185 "Readers-Sound Off," Our Fighting Forces 102 (DC Comics, August 1966).

186 "Death Also Stalks the Hunter," Our Fighting Forces 100 (DC Comics, May 1966); and "No Mercy in Vietnam," Our Fighting Forces 99 (DC Comics, April 1966).

${ }^{187}$ For a more extensive discussion of comics and the Vietnam War, see Wright, Comic Book Nation, 187-199.

188 “Green Berets," Fight the Enemy 2 (Tower Comics, October 1966).
} 
The Green Berets came to his rescue, overlooking his having abandoned their patrol, and Davis promised to return to Vietnam "wearing a green beret." 189 While hardly a nuanced story, it did demonstrate the ways in which Americans made sense of a war that seemed different, confusing, and threatening through the promise of the men of the Green Berets.

Indeed, many of these comics read like recruiting stories for Special Forces. Army Attack, for instance, featured a story titled "Is This the Hat for You?" which laid out standards and training qualifications. But the picture of the soldiers painted by these comics was nothing that had ever existed in reality, though many Americans believed that it did, and that expertise in unconventional warfare would herald America's victory over the communist threat in Southeast Asia. Army Attack proclaimed that "it takes a man to reach out and set" the green beret on his head. ${ }^{190}$ Once he did, he would be surrounded by men who spoke "as many as ten" languages, who were expert frogmen, parachutists, or small boat handlers, men who would "improve the country and people around them" when they deployed, teaching the people with whom they worked "how to live better." 191 In other words, these American soldiers would make the world a better place, a place remade in America's image.

Even while bringing democracy to war torn countries, these elite soldiers could have a little bit of good American fun, like "Muggsy," the "Bird Colonel" from Army Attacks, whom the Army brass tried to keep deskbound in Saigon. In Special Forces, though, you couldn't keep a good man down and Muggsy, "the most valuable combat man” in Vietnam, ignored official orders and helicoptered into a village. Dozens of Green Berets followed him, parachuting in

\footnotetext{
189 “The Draftee," Fight the Enemy 3 (Tower Comics, March 1967).

190 "Is This the Hat for You?" Army Attack 2 (Charlton Comics, December 1966).

191 "Is This the Hat for You?" and "What Comes with the Green Beret," Army Attack 2 (Charlton Comics, December 1966). In reality, language proficiency remained a problem among U.S. advisors throughout the war. See Jeffrey J. Clarke, Advice and Support: The Final Years, 1965-1973 (Washington, DC: US Army Center of Military History, 1988), 62.
} 
"noiseless and determined," until twenty Chinese communists were dead and 400 Viet Cong were trapped. Even then, the colonel refused to return to headquarters and snuck off on another self-appointed mission. ${ }^{192}$

Similar myths perpetuated in the comics included a story in which a Green Beret used a "rocket jumping belt," much like the one demonstrated during Kennedy's visit to Fort Bragg, to singlehandedly attack a convoy of Viet Cong. The enemy died while screaming "Die, imperialist aggressor!" and the lone American soldier expounded on how he was meant to fight "the bullies who inflicted terror on unarmed villagers all over Vietnam" and all around the world. ${ }^{193}$ The first volume of War Heroes saw Green Beret "advisors" refusing to shoot enemies, resorting instead to martial arts skills to disarm threats. They only used guns in defense or to save the life of a child-a chivalric concept that was outdated long before the comic's publication in $1965 .{ }^{194}$

Unlike DC's Capt. Hunter, these stories all displayed an innocence that was reflective of Kennedy's new frontier soldiers. The Green Berets in these comics may have disobeyed orders and saved runaway draftees, but they had a purity of heart that elevated them above the violence of their actions. And while some scholars have been dismissive of the silliest comic story of the genre, Super Green Beret, it was more a purification of the myth than a divergence. ${ }^{195}$ Tod Holton, the comic's hero, was a young boy who received magical superpowers when he donned his green beret. With them, he became a "super soldier," who battled oppression and injustice

\footnotetext{
192 "Peking Plan,” Army Attack 2 (Charlton Comics, December 1966).

193 "The Bully," Fightin' Army 1 (Charlton Comics, December 1965).

194 "Non Combatant," War Heroes 1 (Charlton Comics, November 1965).

${ }^{195}$ One scholar called the comic a "poorly conceived and badly executed idea." See Wright, Comic Book Nation, 193. Another scholar said the series was "poorly written and conceived, even by the standards of the comic book industry," while acknowledging that its underlying conceit "was an integral part of the national mythos in mid-1960s America." See Bryan E. Vizzini, "When (Comic) Art Imitates Life: American Exceptionalism and the Comic Book Industry in the Vietnam War Era," in The Vietnam War in Popular Culture: The Influence of America's Most Controversial War on Everyday Life, vol. 1, During the War, ed. Ron Milam, (Santa Barbara: Praeger, 2017), 366.
} 
"the whole world over."196 However, Holton simply accomplished through magical powers what the Green Berets in other comics accomplished through their training and righteousness of cause and ideology. The means might have been different, but the fairy tale was the same.

By late 1966, the idea that there was a "Green Beret myth" had become well-established. Look magazine published an article reminding their readers that "the Special Forces in Vietnam has scant opportunity for the blood ' $\mathrm{n}$ ' thunder antics attributed to it in novels, comic strips and pop songs at home." 197 Nine pages of prose and photographs highlighted the noble efforts of three men from a Special Forces team in Dak Pek: a fighter, a healer, and a builder. The "fighter" was pictured wearing brass bracelets and a beaded necklace, evidence of his "blood-brother acceptance by the montagnards." 198 The "healer" carried his rifle only "grudgingly" while administering medical aid to villagers. ${ }^{199}$ The "builder" was a "gunslinging schoolteacher," whose job it was "to guide the montagnards into the 20th century." The article noted he was "one of the few Americans to learn" the tribal dialect and he was in the process of "devising an alphabet for the tribe." ${ }^{200}$ But this image of the Green Berets, as the soldiers who had proven they could "master the kind of wars Americans are going to have to learn how to fight," was no less a myth than were the "blood 'n' thunder antics" of their popular culture portrayal. ${ }^{201}$ Once again, the Green Berets had demonstrated their ability to be all things for all people.

\footnotetext{
${ }^{196}$ Super Green Beret 1 (Milson Publishing Co., April 1967); and Super Green Beret 2 (Milson Publishing Co., June 1967).

${ }^{197}$ Christopher S. Wren, “The Facts Behind the Green Beret Myth,” Look, November 1, 1966, 28-29.

198 The fighter's combat skills are mentioned in passing: "He turned a trail not long ago to find seven Vietcong staring at him. He shot first, dropped six of them before they got the carbines off their shoulders, chased the seventh through brush until he lost sight of the bloodstains." However, the fighter does not speak the tribal dialect and relies on an interpreter to command his native troops. Ibid., 30-31.

199 If Dak Pek "ever held an All-Star contest" then medic Sergeant First Class Jesse Gonzales, would "sweep the field." The articles stated that medics such as Gonzales "have done more to win over the montagnards than anyone else." Ibid., 32-33.

${ }^{200}$ The "builder," First Lieutenant Richard Gladfelter, ran the civic-action program with "the bounce of a misplaced Peace Corpsman." He set up schools, distributed aid and clothing, and helped the village improve its livestock. Ibid., 35.

${ }^{201}$ Ibid., $28,36$.
} 
Public interest in the Green Berets waned somewhat as the war in Vietnam dragged on. ${ }^{202}$ However, John Wayne's 1968 box-office triumph, The Green Berets, refocused the country's attention. Less a retelling of Moore's novel and more an idealized vision of the Green Beret as savior, the film was the final Vietnam-era contribution to the mythology. To obtain the necessary assistance in making the film, Wayne had written directly to President Johnson, explaining that he wanted to let Americans know "what's going on over there." ${ }^{203}$ Before filming could begin, however, the military had to approve a script, a back-and-forth process which took approximately eighteen months. ${ }^{204}$ Ultimately, the film was produced with the full support of the U.S. Army. As one of the directors said during filming, "You wouldn't get these planes and these choppers and these soldiers and everything around here unless they wanted this picture made."205 Just as Moore's novel and Sadler's song had been, Wayne's movie was panned by major media critics but embraced by many lesser media outlets and the public. ${ }^{206}$ One critic in Pennsylvania found Wayne's film less of the “crackerjack" adventure story that Moore's best seller had been, calling the film a "cliché ridden, wooden account" of Green Beret missions in Vietnam. ${ }^{207}$ A critic in Minnesota thought the film's violence was “almost like watching two scorpions fight to the death in a glass box. How do you choose sides?"208 Others found cross-

\footnotetext{
202 One Special Forces master sergeant claimed that in the war's "halcyon years," the "Green Berets were Vietnam, baby." Until Wayne's film came out, some Special Forces soldiers "were convinced that everyone had forgotten about them." But Green Berets "like to fight and like the world to know about it" and were glad to be back "on the war's center stage again." Gene Roberts, "Green Berets Blossom Again," Raleigh News and Observer, September 3 , 1968.

${ }^{203}$ Joan Barthel, “This picture is naturally from the hawk's point of view,' says John Wayne, Superhawk,” New York Times, December 24, 1967. In a now infamous 1971 interview with Playboy, Wayne described The Green Berets as "an American film about American boys who were heroes over there. In that sense it was propaganda." Richard Warren Lewis, “John Wayne: Playboy Interview,” Playboy, May 1971, 88.

${ }^{204}$ For an account of how the film came to be made, see Suid, Guts and Glory, 247-256.

${ }^{205}$ Joan Barthel, "This picture is naturally from the hawk's point of view,' says John Wayne, Superhawk," New York Times, December 24, 1967.

${ }^{206}$ The soundtrack for the movie's opening and closing credits is "The Ballad of the Green Berets."

${ }^{207}$ Thomas Blakley, "Big Jawn Heads Green Berets," Pittsburgh Press, July 9, 1968.

${ }^{208}$ Don Morrison, “2 Cents’ Worth,” Minneapolis Star, June 28, 1968.
} 
country fault with both the critical reviews from the "New York weirdos" and the failure of the Hollywood "liberals and their media flunkies" to produce more anti-communist films. ${ }^{209} \mathrm{~A}$ columnist in Arizona, while noting the film was a "mixed bag," attributed the critical censure to Wayne's "temerity to film a movie" that offended the critics" "political views." 210 A reviewer from Mississippi agreed, remarking that "despite the contempt so many pinkish critics have for him," Wayne was one of America's top talents. The reviewer opined that the box-office success of Wayne's film indicated that America supported our "fighting men in Vietnam," the heroes who helped "hold the line against Communism."211

The scholarly literature on Wayne's film tends to focus on the withering critical reviews, the military's involvement in the script, and its value and intent as propaganda. ${ }^{212}$ And it may indeed be true that, as one scholar argues, the "overwhelmingly negative reactions" to the film "revealed how deeply faith in crucial Cold War myths had declined." ${ }^{213}$ However, what is overlooked is that the myth of the Green Berets was in no way diminished by the flaws of the movie. Indeed, even Renata Adler, in her famously caustic review for the New York Times, thought "the film could not be more false or do a greater disservice" to our soldiers. ${ }^{214}$

In fact, most critics who panned the film stopped to acknowledge the exceptionalism of the Green Berets. Time thought Wayne's movie was an "absurd and blundering epic.” However,

\footnotetext{
209 Tom Ethridge, "Mississippi Notebook," Clarion-Ledger, February 3, 1969.

${ }^{210}$ Edwin McDowell, “Green Berets, despite Loud Sniping, Doing ‘Boffo’ Business at Box Office,” Arizona Republic, July 7, 1968. While the film was a commercial success, it was not without controversy. Anti-war demonstrators picketed theaters in several states, including Atlanta, Georgia, where a man punched a young woman in the face after she called John Wayne a "warmonger." B.J. Phillips, "Patriots Came in Two Size," Atlanta Constitution, July 8, 1968.

${ }^{211}$ Tom Ethridge, "Mississippi Notebook," Clarion-Ledger, February 3, 1969.

212 Some examples include Lawrence Suid, "Hollywood and Vietnam," Film Comment 15, no. 5 (SeptemberOctober 1979): 20-25; Jon Cowans, “A Deepening Disbelief: The American Movie Hero in Vietnam, 1958-1968," Journal of American-East Asian Relations 17, no. 4, Theme Issue: Film Across the Pacific: Projections, Screens, and Mirrors - Part One (2010): 324-351; and Gilbert Adair, Hollywood's Vietnam: From The Green Berets to Apocalypse Now (New York: Proteus, 1981), 35-52.

${ }^{213}$ Cowans, "A Deepening Disbelief," 349.

${ }^{214}$ Renata Adler, “Screen: ‘Green Berets’ as Viewed by John Wayne,” New York Time, June 20, 1968.
} 
"the real Green Berets," run "the most economic and perhaps the most unusual operation in the war," with a "seemingly limitless supply of gall and resourcefulness." 215 The New York Times published an article, "U.S. Special Forces: Real and on Film," alongside Adler's review. The article found that while authenticity was "one of the earliest" casualties in the movie, the real-life soldiers of the Special Forces were "wonderfully proficient, likeable men."216 A reviewer for the Atlanta Constitution called the film a two and a half hour "paean to the Special Forces," which was "a valid intention." Unfortunately, the one-dimensional characters and wooden dialogue were "unfair to the members of the Special Forces."217

The movie is also useful in revealing the image that the military had of itself and of the war it was fighting in Vietnam. ${ }^{218}$ The Army had stated it would not approve a script unless it conformed "with the mission of Special Forces in Vietnam."219 The fact that it approved the script and gave Wayne's production the requested assistance indicates that this was a story the Army and the Department of Defense wanted told. But to dismiss this as propaganda overlooks its revelatory value. If we examine the film, several salient scenarios emerge: at least three members of Colonel Kirby's team spoke Vietnamese, the South Vietnamese commander with whom the Americans allied themselves was a true leader and a good soldier, and when the Green Berets demonstrated their good intentions, the local villagers were quick to believe in them and

215 “The Real Berets," Time, July 19, 1968, 33.

${ }^{216}$ Charles Mohr, "U.S. Special Forces: Real and on Film," New York Times, June 20, 1968; and Renata Adler, "Screen: 'Green Berets' as Viewed by John Wayne," New York Time, June 20, 1968.

${ }^{217}$ Diane Thomas, "Green from 'The Green Berets' Descends to Reviewer's Gills," Atlanta Constitution, July 8, 1968.

${ }^{218}$ Robert Kreger, a Special Forces veteran, recalled how during the attack on the camp at Dak Seang, his team got a package delivered by two Cobra gunships and a Huey slick. The helicopters came right across the top of their compound and threw a package off to them. In the package was a copy of John Wayne's movie, The Green Berets. Kreger described the team's reaction: "We're just roaring with laughter because we had just been through this battle, we're under siege, and here comes this movie about the Green Berets." Kreger, interview, 107-108. For an account of the battle, see Stanton, Green Berets at War, 188. Many veterans of the Special Forces remember the film fondly. One veteran claimed Moore's book and Wayne's film "are almost biblical." Tim Ghianni, "Fighting Soldiers, Tender Brothers," Tennessean, September 11, 2006.

${ }^{219}$ Suid, Guts and Glory, 250, quoting a letter to Department of Defense Public Affairs. 
stand up to the Viet Cong. ${ }^{220}$ These are all myths, but they are myths that the American militaryand the American public-accepted for much of the United States' early years in Vietnam. Not surprisingly, the Green Berets were not only the personification of these myths. They helped perpetuate them as well.

${ }^{220}$ In the film, Sergeant Muldoon, Doc McGee, and Sergeant Peterson all speak Vietnamese. In reality, despite the media hype of the Green Berets as linguistic wizards, very few spoke Vietnamese or the Montagnard dialects. See Clarke, Advice and Support, 62; and Donald Duncan, The New Legions (New York: Random House, 1967), 189. The Montagnard villagers saw the goodness of the Green Berets after their medic treated the chief's granddaughter, who had been injured by a punji stick. Captain Nim, the Vietnamese commander of the camp Colonel Kirby visited, not only was present for every important decision that had to be made, but he helped the Green Berets set the range on their mortars, had the trust and respect of the American officers, and nobly fought to his death. The reality of the American war in Vietnam was very different, as both Moore's novel and numerous other media reports made clear. For instance, see Moore, Green Berets, 134; and "Friction Affects Vietnam Fighting," New York Times, August 19, 1962. Most media reports referred to the Vietnamese commanders as "nominal" commanders-a "polite fiction." Murray Sayle, "The Green Berets," Sydney Morning Herald, December 6, 1969. Another myth portrayed in the film was that Green Berets would not allow their Vietnamese counterparts to torture prisoners. However, it was widely understood and documented that they did not object to such behavior. For example, see Moore, Green Berets, 50-52; "Ex-GI: Told to Kill PWs," Tennessean, May 25, 1967; and Strassfeld, "Vietnam War on Trial," 914-915. 


\section{Green Berets in Vietnam, 1965-1970}

The popular myth of the Green Berets rested on the assumption that these worldly soldiers of Kennedy's New Frontier would bring American ideals of progress and democracy to the Global South and win the battle against the spread of communism. Their language skills, their extensive military training, their capabilities as teachers, and their medical and scientific prowess would all be applied to the betterment of South Vietnam and the inevitable victory over the communist guerrilla forces of the north. This was not what actually happened in Vietnam, however, where the reality of the war had little relation to the Green Berets' myth.

The U.S. Army Special Forces' viewpoint of the war it was fighting in Vietnam can be ascertained in the pages of their official magazine, the Green Beret. In August 1966, the $5^{\text {th }}$ Special Forces Group began publishing a monthly magazine that highlighted the accomplishments and struggles of teams deployed throughout Vietnam. Until the end of the CIDG program and the withdrawal of most of the Green Berets from Vietnam in 1970, this magazine documented their missions. The brainchild of Colonel Francis Kelly, commander of the Special Forces in Vietnam from June 1966 to June 1967, the magazine was intended to be a source of information and motivation for his men. ${ }^{221}$ Of course, the publicity value of the magazine as a "handout for visiting dignitaries" didn’t hurt Kelly’s cause. ${ }^{222}$

\footnotetext{
${ }^{221}$ While the magazine was an official military publication, and thus reflected only the viewpoint the commander wanted, one editor of the magazine later reflected that the magazine was devoted "to the men in the field." The stories were real and "not some PR-rag that coated everything with a sugary boosterism." Stephen L. Johnson, "Introduction to the Green Beret Magazine," Green Beret 1 (1966): xvi.

222 John C. Browning, "Introduction to the Green Beret Magazine," Green Beret 1 (1966): xii-xiii.
} 
In the words of one New York Times reporter, Kelly took command of Special Forces determined to "restore it to the regular Army, from which a good many of his superiors believed it had strayed." 223 This mindset was reflected in the magazine's reporting, which noted that the "Special Forces soldier is a member of the Army Team, soldiers doing a soldier's job." 224 This was true despite the "many things" that had been "said and written" about the "capabilities and accomplishments of the Green Berets." ${ }^{225}$ While Special Forces Command itself had worked hard to promote media interest in the unit, including publicizing "The Ballad of the Green Berets," the public image had grown beyond their control. ${ }^{226}$ Kelly and other commanders in Vietnam desired to minimize the animosity this had created between conventional units commanders and the Special Forces. ${ }^{227}$

A recurring theme throughout the magazine's run was the importance of the counterinsurgency mission to U.S. strategy in Vietnam. In the magazine's first edition, Kelly argued that the "counterinsurgency situation" required that combat actions be undertaken alongside civic action. The mission began with "finding and destroying the enemy" and ended

\footnotetext{
${ }^{223}$ Kelly took additional actions to rein in his troops: he declared Saigon off limits and "ordered his men to cease wearing certain unauthorized items of equipment such as tiger-skin capes and elephant-hide boots." He also told them to "shave off their handlebar moustaches." This is noteworthy mainly because it indicates there were enough Green Berets serving in Vietnam who wore tiger-skin capes to merit mentioning. Tom Buckley, "Green Berets Try to Shed Reputation as Derring-do Unit," New York Times, January 23, 1967. Another media account quoted an unnamed colonel saying of the Green Berets that "they looked more like lion-tamers than soldiers." Also in fashion had been "tiger-tooth bracelets." Murray Sayle, "The Green Berets," Sydney Morning Herald, December 6, 1969. ${ }^{224}$ Kelly informed his men, "We are not special through the wearing of different uniform mixtures, or careless appearance, or casual courtesy, but through rigid adherence to the standards of a professional Special Forces soldier." Francis J. Kelly, “The Role of the Special Forces Soldier in Vietnam," Green Beret 1, no. 1 (August 1966): 2 . 225 "5th Anniversary," Green Beret 1, no. 3 (October 1966): 19.

${ }^{226}$ Jim Morris, a Special Forces veteran, said the best thing Special Forces could do would be to "maintain a low profile," as the rest of the Army was "jealous enough already." Morris, War Story, 248.

${ }_{227}$ Tom Buckley, "Green Berets Try to Shed Reputation as Derring-do Unit," New York Times, January 23, 1967. For mention of the enmity many conventional commanders had for Special Forces, see Simpson, Inside the Green Berets, 94. In the introduction to the collected volumes of the Green Beret magazine, James Morris claimed that "powerful forces in the Pentagon wanted" Special Forces done away with. He said one of the reasons that didn't happen was because Representative Mendel Rivers of the House Armed Services Committee "got his Green Beret magazine every month." James Morris, "Introduction to the Green Beret Magazine," Green Beret 1 (1966): xiv.
} 
with helping "the Vietnamese people to help themselves." ${ }^{228}$ Articles on medical aid programs, livestock development projects, and other civic action initiatives filled the magazines' pages. In fact, according to the Green Beret, Special Forces was responsible for 42 percent of "total Military Civic Action effort in the Republic of Vietnam" in $1966 .{ }^{229}$ An effort was made to note that these projects were undertaken jointly with the South Vietnamese government and that the townspeople "not only understand and appreciate the efforts being made on their behalf, but also willingly help in the tasks." 230

Success in these projects was something that could be measured: metrics were what mattered. One article listed numbers of medical treatments, construction projects, and poundage of aid delivered in support of the statement: "All this indicates that civil activities are keeping abreast of military operations." 231 Other articles simply equated aid disbursement with winning the support of the people. For instance, when the Viet Cong burned the village of Khoa Truong, American and Vietnamese Special Forces soldiers worked hand in hand to help get the villagers back on their feet. The local people saw the results of the project and their attitude "changed

\footnotetext{
${ }^{228}$ Kelly was careful to clarify that "the notion that civic action detracts from or is superior to combat action is erroneous and is the reverse." But while combat action was "superior," it was civic action the magazine highlighted time and time again. Francis J. Kelly, "The Role of the Special Forces Soldier in Vietnam," Green Beret 1, no. 1 (August 1966): 2. Kelly again emphasized the primacy of combat in his farewell letter to his troops at the end of his tour of duty. Kelly said he "set the mission of the Group to find the enemy and destroy him," a mission that was accomplished in "magnificent fashion" by the Special Forces, the soldiers of "destiny." Francis J. Kelly, "Letter from the Group Commander," Green Beret 2, no. 5 (May 1967): 3. The precise relationship between combat operations and civic action was never clear and was presented in different ways at different times. For example, a different article in the Green Beret compared the operations of 5th Special Forces Group to a table, with the legs being military operations, intelligence, civic action, and psychological operations. Together, these four made a "balanced Special Forces program in Vietnam." "5th Special Forces Group History," Green Beret 2, no. 9 (September 1967): 7.

229 "1966 - A Successful Year for Rev Dev," Green Beret 2, no. 2 (February 1967): 22.

230 "IV Corps 'A' Camps: Camp Ha Tien," Green Beret 1, no. 4 (November 1966): 11. Other such articles include “II Corps' Camp Mang Buk,” Green Beret 2, no. 3 (March 1967): 6-7; "I Corps' Camp Gia Vuc," Green Beret 2, no. 5 (May 1967): 5; "II Corps Camp: Cung Son,” Green Beret 2, no. 8 (August 1967): 11; and J. Kringel, “Tieu Atar," Green Beret 3, no. 11 (November 1968): 8-9.

231 "IV Corps 'A' Camp," Green Beret 2, no. 7 (July 1966): 15.
} 
from apathy, to support of the government." 232 This assertion was the same one made in

Wayne's film: good deeds win hearts and minds.

As if to demonstrate these elite soldiers' ability to shed their "ugly American" ways and work side-by-side with the locals, articles also referenced examples of American and Vietnamese cooperation. During one assault, a Special Forces officer noted how proud he was to have the Vietnamese troops in his command. ${ }^{233}$ Pictures that accompanied the magazine's articles show Vietnamese officers and American soldiers working alongside each other as co-equal partners. ${ }^{234}$ However, this image of amicable working relations was belied by a message from the Special Forces commander in early 1969. Colonel Harold Aaron informed his men that "the respect of the Vietnamese military and civilians must be maintained or the entire US effort in Vietnam is in danger of being nullified." To that end, he instructed commanders to take "vigorous" measures to ensure proper conduct towards the Vietnamese Special Forces. ${ }^{235}$ However, problems remained, because several commanders later, the men of $5^{\text {th }}$ Special Forces Group were reminded that "a close and harmonious relationship" with Vietnamese Special Forces soldiers was of the "utmost

\footnotetext{
${ }^{232}$ Richard Allen and Darrell Daniel, "Ha Tay CA Hits High Gear," Green Beret 3, no. 6 (June 1968): 19. In reality, as Kelly himself later admitted, the "attitude of the Vietnamese and even the people involved, occasionally, was disappointingly indifferent." Kelly noted that many Special Forces teams reported the "unsympathetic attitude" of the Vietnamese Special Forces toward the civilian population. He also said that larger community-improvement projects were not successful, as "the concept of cooperative self-help...seemed foreign to their nature or cultural patterns.” Kelly, U.S. Army Special Forces, 62-63.

233 "Two Chicom Anti-aircraft Guns Captured by Mike Force Unit," Green Beret 1, no. 4 (November 1966): 19.

${ }^{234}$ For instance, see Frank J. Lewis, “Dong Xoai-A Success Story," Green Beret 3, no. 12 (December 1968): 20-21. The article featured two pictures of American and Vietnamese soldiers discussing "supply requisitions" and planning "the day's work." Another such article showed American and Vietnamese Special Forces soldiers enjoying a feast together, as well as pictures of the Vietnamese camp commander and his American counterpart attending the opening ceremonies for a civic action project. Bob Rounsefell, "Four New School for Gia Vuc," Green Beret 4, no. 1 (January 1969): 10-11.

${ }^{235}$ Harold R. Aaron, "Personal Conduct," Green Beret 4, no. 1 (January 1969): 2.
} 
importance" in accomplishing the mission. ${ }^{236}$ Soldiers were ordered to share information, to coordinate their operations, and to "approach problem areas with understanding and insight.".

In early 1968, the editor of the Green Beret magazine, Jim Morris, wrote an article about the overly glamorized image of Special Forces. He noted that because stories of "action, passion, adventure, sex" are what readers prefer, those are the articles that get published. ${ }^{238}$ Even though much of the success of Special Forces-"even combat success"-was due to civic action, few readers were interested about stories not tied directly to battlefield combat. ${ }^{239}$ Morris recommended that soldiers stop worrying about their image and just get on with doing their jobs: "winning this war." ${ }^{40}$ However, Morris himself had decided to join the Army after reading an article in the Saturday Evening Post that was heavy on action, adventure, and the excitement of

\footnotetext{
236 There was a related story that was never mentioned in the magazine, but which was responsible for the rapid personnel turnover in summer 1969. Colonel Robert Rheault assumed command of $5^{\text {th }}$ Special Forces Group in May 1969, and was arrested less than two months later for his involvement in the execution of a suspected Vietnamese double agent. Charges against him, and the seven other Green Berets who had been arrested, were dropped when the CIA declined to make its personnel available to testify in the proceedings. See Homer Bigart, "Beret Affair: Step by Step in the Case of the Suspect Agent," New York Times, October 6, 1969. General Creighton Abrams, by all accounts no fan of the elite unit, then appointed one of his headquarters staff officers, who was not airborne qualified, as commander of the $5^{\text {th }}$ Special Forces Group. Several days after assuming command, Colonel Alexander Lemberes broke his ankle while jumping out of a helicopter during airborne training in Dong Ba Thin. Lemberes was replaced by Colonel Michael Healy the following month. See Chalmers M. Roberts, "New Beret Chief Named in Vietnam: Newly Named Beret Chief Replaced," Washington Post, August 29, 1969. For an account of the "Green Beret Affair" and the fallout, see Stanton, Green Berets at War, 194-199. Life ran a sympathetic cover story on Colonel Rheault that featured a quote from his young son: "What's all the fuss about? I thought that's what Dad was in Vietnam for-to kill the Vietcong." Frank McCulloch, "The Fall of a 'Lost Soldier,"” Life, November 14, 1969, 38. ${ }^{237}$ Alexander Lemberes, "Commander's Call," Green Beret 4, no. 9 (September 1969): 2. In 1970, a subsequent commander of $5^{\text {th }}$ Special Forces Group referred to his counterparts as "the gallant Vietnamese Special Forces." See Michael D. Healy, "Commander's Call," Green Beret 5, no. 2 (February 1970): 2.

${ }^{238}$ An extreme example of this was seen in men's action magazines of the era. For instance, see Mario Cleri, "Saigon Nymph Who Led the Green Berets to the Cong's Terror Headquarters," Male 16, no. 8 (August 1966): 1284. The cover of the magazine featured a Special Forces team boldly "repelling" the enemy. Green Berets can also be found on the covers of the following men's magazines: Man's Life (September 1966), Male (July 1966), and Man's Epic (March 1968). For a study of these publications and their contribution to the era's notions of masculinity and conquest, see Gregory A. Daddis, Pulp Vietnam: War and Gender in Cold War Men's Adventure Magazines (New York: Cambridge University Press, 2021).

${ }^{239}$ Morris had a humorous section in the editorial: "The standard image of Special Forces is that of a guy with a five-day growth of beard, in a camouflage war suit, groping through the jungles with a knife in his teeth! That's all well and good; but if you goof it, you'll cut your mouth real bad. Besides, cold steel makes your fillings ache; and the only way to keep the knife from rusting is to coat it with Vaseline. Who wants a mouthful of Vaseline?' Jim Morris, "Images," Green Beret 3, no. 1 (January 1968): 14.

${ }^{240}$ Ibid.
} 
killing. ${ }^{241}$ When he arrived in Vietnam and was assigned to work on the Green Beret, he complained that it was a "useless" job. All Morris wanted to do "was get back out in the woods with troops, kill some VC, and get the old adrenalin flowing." ${ }^{242}$

Morris was not the only Green Beret who had been inspired by these warrior visions or who desired to test the notions of manhood being the result of surviving through the crucible of war. Veteran Bill Siemer described his own motivation in a poem:

I didn't come here

For the cause they tout

The slogans they spout

Killing a commie for Christ

Is not what I'm about

I came to see

What war does to me..$^{243}$

Siemer explained that his father had never gone to war and that it "left him wondering if he owed the store." Siemer felt that he had a duty to pay his father's "tab" and, in the process, become a man himself. ${ }^{244}$ Others were intrigued by the idea of being "jungle killers" or professional soldiers, finally able to put their many months of training to the test in Southeast Asia. ${ }^{245}$

Despite the popular media's infatuation with combat, and veterans' curiosity about it, the heart of the Special Forces mission in Vietnam was the CIDG program. And while the Americans were mostly successful in gaining the loyalty of the Montagnard tribes, this loyalty

\footnotetext{
${ }^{241}$ Morris, War Story, 160. The article included a photo of a man with face paint and a knife, advancing stealthily towards an enemy sentry, and a caption that explained the sentry "must be exterminated-quickly and quietly." Blair, "Toughest Outfit in the Army," 41.

${ }^{242}$ Morris went on: "Maybe I haven't made this strong enough. To me commanding an SF A detachment was the pinnacle of ambition. I would rather command an A detachment in the highlands of Vietnam than be president of the United States or win the Nobel Prize for Literature...It was all I had wanted to do since I learned there was such a thing." Morris, War Story, 200-201, 249. While Morris was not given command of another team, he did tag along on a few Project Delta missions while working for the Green Beret. During one of these missions, Morris was shot in the arm and eventually medically retired from the Army.

${ }^{243}$ Bill Siemer, Skeletons to Find: A Vietnam Diary (self-published, 1st Books Library, 2003), 15.

${ }^{244}$ Ibid., 6.

${ }^{245}$ David Mark Mantell, True Americanism: Green Berets and War Resisters, A Study of Commitment (New York: Teachers College Press, 1974), 152-153.
} 
did not transfer seamlessly to the Saigon government, the overriding objective of American strategy in South Vietnam. ${ }^{246}$ The Montagnard uprisings of 1964 and 1965 were but two of the most visible results of this inability to truly pacify the countryside and indicated that while these troops might be an effective fighting force in the short term, their long-term willingness to support the local, noncommunist government could not be guaranteed. ${ }^{247}$

Indeed, there were some within Special Forces who themselves would have sided with the Montagnards over the government of South Vietnam. ${ }^{248}$ Many Green Berets shared the opinion of Robert Kreger, who had the "utmost respect" for the Montagnard people. ${ }^{249}$ Jim Morris, in relating his time in Vietnam, said he was a soldier because he "loved the Montagnards, the jungle and parachuting." A decade after his three deployments to Vietnam, he described himself as "as much Montagnard as American," because he had staked his life for their cause. ${ }^{250}$ An Army physician who studied Special Forces noted that while "relations with their Vietnamese counterparts are always strained," team members "make a strong distinction between the Vietnamese and the Montagnard soldiers." ${ }^{251}$ Another soldier remarked that the men of

\footnotetext{
${ }^{246}$ This had been mentioned as early as 1962 in media coverage of the CIDG program. For example, see David Halberstam, "Salt Helps U.S. Win Vietnamese," New York Times, December 21, 1962. Halberstam wrote "the affection of the Montagnards is primarily to the Americans and not necessarily to the South Vietnamese Government of President Ngo Dinh Diem.

${ }^{247}$ Animosity between the Montagnards and Vietnamese predated American involvement in Vietnam. In the uprising of 1964, Montagnard fighters from five CIDG camps revolted against the government of South Vietnam and presented a list of demands. The intervention of Special Forces soldiers ended the revolt, though not before dozens were killed. Another, smaller uprising occurred in 1965. See Stanton, Green Berets at War, 84-88; Howard Sochurek, "Americans in Action in Vietnam," National Geographic, January 1965; and Jack Langguth, "Montagnard Revolt in Vietnam Believed Averted," New York Times, January 26, 1965. In 1967, a group of Montagnards became ill and some died after attending a social event. The Montagnards claimed the Vietnamese had poisoned the liquor and other reports of poisonings were later reported. A U.S. Army doctor said, "it's one big powder keg here just ready to explode." Another American official said he hoped the Viet Cong were responsible. Denby Fawcett, "Montagnard Poisonings Put Vietnamese on Edge," Honolulu Advertiser, April 30, 1967.

${ }^{248}$ See Duncan, The New Legions, 216.

${ }^{249}$ Kreger, interview, 130.

${ }^{250}$ Morris, War Story, 6, 22. One media account claimed that of the "nine Medals of Honor won by Green Berets in Vietnam, four were won by men risking their lives to save their CIDG comrades." George McArthur, "Our Job's Done'-Berets Leaving Vietnam," Miami Herald, February 26, 1971.

${ }^{251}$ Peter G. Bourne, Men, Stress, and Vietnam (Boston: Little, Brown and Company, 1970), 114.
} 
Special Forces "saved their dislike for the Vietnamese and were openly contemptuous of their indigenous counterparts." ${ }^{252}$ Such paradoxes, however, never made their way into official wartime publications lest the Saigon government become offended.

Another aspect of the Green Beret mythology that diverged widely from the reality of the Vietnam era was the Americans' supposed linguistic mastery. One Green Beret medic said he had never met a fellow Green Beret who spoke Vietnamese and had only even heard of a single Special Forces soldier who spoke fluent Vietnamese. ${ }^{253}$ Another soldier joked, “Sure, I'm bilingual. I talk English and vulgar." ${ }^{254}$ If you excluded German, Spanish, and French, the number who spoke a foreign language was described by one veteran as a "fractional minority." ${ }^{255}$ Robert Shippen, who had received some language training at Fort Bragg, conceded that he couldn't really speak Vietnamese, or even understand it. ${ }^{256}$ "Almost useless," was how another soldier described the "superficial" training he had received before deploying. ${ }^{257}$ Others admitted that despite the romantic media image, "few if any" Green Berets were close to the level of expertise the public imagined. ${ }^{258}$

In fact, many soldiers became increasingly skeptical that the civic action projects they were involved in could win the loyalty of the local people. Special Forces medic Aaron

\footnotetext{
${ }^{252}$ Duncan, The New Legions, 216.

${ }^{253}$ Thomas Hepburn Perry to wife, tape recording, May 9, 1968, Thomas Hepburn Perry Vietnam War Correspondence (2018-093-wc), Center for American War Letters, Chapman University, CA (hereinafter Perry Correspondence). This soldier took it upon himself to learn enough of the language that he was eventually able to explain a skin graft to a patient without the need of an interpreter. See Perry to wife, February 15, 1968, Perry Correspondence.

${ }^{254}$ Wren, "The Facts Behind the Green Beret Myth,” 35, quoting an unnamed Special Forces lieutenant.

${ }^{255}$ Duncan, The New Legions, 189.

${ }^{256}$ Shippen noted his training mainly included "real basic stuff like, mostly medical terms and body parts." Shippen, interview, 95.

${ }^{257}$ Kreger, interview, 52.

${ }^{258}$ The author specifically mentioned cross-training in team skills, foreign language ability, and weapons knowledge as areas of deficiency. See Bourne, Men, Stress, and Vietnam, 110. In 1966, an Army evaluation team reported that "the effectiveness of United States Army Special Forces operational detachments is seriously limited by a lack of personnel who could speak the language of the area of operations." Department of the Army, Army Concept Team in Vietnam, Employment of a Special Forces Group, April 20, 1966, 60.
} 
Gritzmaker, who participated in several such projects in Tra Bong felt that "we were not winning the hearts and minds by any means." Nevertheless, he enjoyed being a "cowboy" in the "Wild West" and claimed he would probably still be there "if the war was still going on." ${ }^{259}$ Norm Gardner, an executive officer of a Special Forces team west of Nha Trang, was responsible for implementing his team's civic action projects. While he believed in the concept of civic action, he found that in reality it was more of a "slap dab effort," with no long-term planning. As "commands changed, as people changed, efforts changed," making continuity and planning virtually impossible. His team refurbished schools, subsidized teachers' salaries, and rebuilt bridges, which he believed the people appreciated. However, he noted that appreciation did not translate into winning the support of the people. In his view, "they would just take whatever they could get from whoever gave it and do the best they could."260

The concept of Green Berets as enlightened soldiers who won the hearts of native people everywhere simply did not accord with reality. Medic Thomas Perry wrote home to his wife daily before he was killed in action during a rescue mission. Perry worked at the hospital in $\mathrm{Da}$ Nang, where he came into contact with scores of other soldiers. A draft-motivated enlistee, Perry joined the Special Forces because he believed Kennedy's counterinsurgency aim of winning hearts and minds through civic action. However, after having been in Vietnam for several months, he was disgusted by the "absolutely appalling treatment of the Vietnamese people" that he daily witnessed. Vietnamese people were not allowed to be transported in U.S. military vehicles without proper paperwork. Local nationals were not allowed to drink in the American

\footnotetext{
${ }^{259}$ Aaron Gritzmaker, interview with Jason Stewart, September 29, 2008, transcript, Oral History Project, Vietnam Archive, Texas Tech University, 25, 48.

${ }^{260}$ Norm Gardner, interview with Stephen Maxner, March 14, 2001, transcript, Oral History Project, Vietnam Archive, Texas Tech University, 8, 13. For a study of the effectiveness of military medical aid programs in Vietnam, see Robert J. Wilensky, Military Medicine to Win Hearts and Minds: Aid to Civilians in the Vietnam War (Lubbock, Texas: Texas Tech University Press, 2004). For a discussion of the ethical considerations of using medicine as a political weapon, see Strassfeld, "Vietnam War on Trial," 930-941.
} 
clubs on base and large signs on U.S. officer and enlisted latrines read "American only." The Vietnamese soldiers were forced to use the "sorriest, smallest latrine on the compound."261

This discrimination also took place at the personal level, and while it might not have been noteworthy in a "normal" military operation, in counterinsurgency warfare, winning the support of the local people was everything. Perry observed that the professional U.S. soldiers, those who had made the military their career, treated the locally hired help abysmally. The Vietnamese men were "ignored unless they fail[ed] to perform their duties," in which case they were forced. But Perry was especially critical of how the women were regarded.

The women are all treated like tramps. They are fondled, insulted, slapped on the ass, screamed at, driven to tears, bear hugged; they are constantly and continuously approached sexually, no matter how married, how many children, how ugly. It is behavior which generates loathing on the part of the indigenous women. There is a tenseness about the women here (the secretaries, floor sweepers, nurses) that underlies their participation in the banter, flirting, and sexual passes they are in contact with here every day. ${ }^{262}$

The mistreatment of Vietnamese women intimated much deeper problems with the myth of the Green Berets. In reality, the American war in Southeast Asia turned out to be far more complicated than popular myths promised. The political-military struggle inside South Vietnam proved far messier, far more difficult to control than most Americans had anticipated. Even highly trained soldiers, like those who wore the green beret, could not solve local social, political, and economic problems over which the Vietnamese themselves were fighting. True, these men were highly skilled in combat and trained in nonmilitary endeavors like civic action and pacification. Yet this training, on which so many of the myths were founded, could not resolve what, at its core, was always an internal Vietnamese struggle. In the end, the American myths of the heroic, unvanquished Green Beret never lived up to their promises.

\footnotetext{
${ }^{261}$ Perry to wife, March 29, 1968, Perry Correspondence.

262 Perry to wife, January 16, 1968, Perry Correspondence, emphasis in original.
} 


\section{Conclusion}

By early 1971, the last of the CIDG camps were transferred to the Republic of Vietnam's Armed Forces and the Green Berets ceased to function as an official unit in Vietnam. Yet even as the American war was coming to a close in Southeast Asia, the public had not entirely lost interest in these elite soldiers and numerous media articles wondered what would happen to "yesterday's heroes" now that they had returned home. ${ }^{263}$ In fact, much of the media coverage remained flattering, despite the downturn of support for the war. The Miami Herald proclaimed that the "fabled Green Berets" had a "proud role" in Vietnam. Other, lesser, units might have "long since lost most of their identity in Vietnam," but the Green Berets "played their own game to the end."264 Meanwhile, Time announced that "as the war has turned, the nimbus of heroism dissolved" from these "Apaches with diplomas from Fort Bragg." 265 But the coverage reflected more a diminished enthusiasm for America's aims in Vietnam than dissatisfaction with the Green Berets themselves. There was almost a feeling of disappointment in the reporting, a nostalgia for the past promise of a triumphant future that had dimmed. And though most articles again parroted the litany of their skills, the underlying concern seemed to be what would become of them now.

Throughout the 1970s, newspapers continued to publish articles about the Green Berets, and reporters kept track of their fortunes as they did no other military unit. The war may have "eventually slipped out from under their combat boots," but they were "tough, patriotic, God-

\footnotetext{
${ }^{263}$ Robert A. Dobkin, "New Role for Green Berets," Raleigh News and Observer, January 24, 1971.

${ }^{264}$ George McArthur, “'Our Job’s Done'-Berets Leaving Vietnam,” Miami Herald, February 26, 1971.

265 "Goodbye to All That," Time, February 8, 1971, 8.
} 
fearing men" nonetheless. ${ }^{266}$ Perhaps the wistfulness had something to do with their having left Vietnam before the war was truly lost in the eyes of the American public. Regardless, the Green Berets were distinct from other Vietnam veterans. They never belonged to the paradigm of "innocence savaged and destroyed" by war, as Paul Fussell argues happened in World War I or as historian Christian Appy shows developed into one of the postwar cultural myths from Vietnam. ${ }^{267}$ Media reports referred to the "fabled Green Berets" as possibly the "only American soldiers who liked the Vietnam war." 268 A writer for the Associated Press stated "the mere mention of the Green Berets conjures up images of men who loved the danger and excitement of war in Southeast Asia."269

Even early post-Vietnam media portrayals of the veteran as victim held the Green Berets in an elevated regard relative to other combat soldiers. In The Deer Hunter, it was Michael, the Green Beret, who was triumphant and whose skills freed his friends from captivity. His psychological wounds are superficial, in contrast to the paralyzing physical and mental injuries of his friends, Steven and Nick. ${ }^{270}$ Those who had been to Vietnam found little they recognized in director Michael Cimino's film, but that did not stop audiences from filling theaters or Hollywood from nominating The Deer Hunter for nine Academy Awards. ${ }^{271}$ Despite its billing as an anti-war film, The Deer Hunter actually perpetuated American notions of heroism and

\footnotetext{
266 "Goodbye to All That," Time, February 8, 1971, 8; and "The Green Berets," Raleigh Register, June 3, 1974.

${ }^{267}$ Paul Fussell, The Great War and Modern Memory (New York: Oxford University Press, 1975, 2013), 362. Appy argues that though "innocence savaged and destroyed" by war was persistent in popular culture, soldiers were never quite as innocent as society believed them to be. Christian G. Appy, Working-Class War: American Combat Soldiers and Vietnam (Chapel Hill: University of North Carolina Press, 1993), 80-85.

${ }^{268}$ George McArthur, “'Our Job's Done'-Berets Leaving Vietnam,” Miami Herald, February 26, 1971.

${ }^{269}$ Monte Plott, "Berets Still Ready," Dayton Daily News, June 2, 1978. On the portrayal of the Vietnam veteran as victim, see Andrew J. Huebner, The Warrior Image: Soldiers in American Culture from the Second World War to the Vietnam Era (Chapel Hill: University of North Carolina Press, 2008), 237-240.

${ }^{270}$ Steven lost both of his legs in the war and Nick suffered a complete mental breakdown. An example of a study on masculinity in The Deer Hunter is Susan Jeffords, The Remasculinization of America: Gender and the Vietnam War (Bloomington: Indiana University Press, 1989), 94-102.

${ }^{271}$ For critical reviews, see Peter Arnett, "The Deer Hunter: Vietnam's Final Atrocity," Los Angeles Times, April 8, 1979; and Tom Buckley, “Hollywood's War,” Harper's, April 1979, 84-88.
} 
patriotism through the myth of the Green Berets. ${ }^{272}$ Their legend as "super-soldiers" had survived a bloody and unpopular war, both in news media accounts and on the big screen. ${ }^{273}$ So when the film won the Academy Award for Best Picture in 1979, it was only fitting that John Wayne, the gunslinging patriot himself, presented the award. ${ }^{274}$

It was not until the 1980s, however, that the Green Berets appeared on the silver screen in all their masculine glory. During the Reagan presidency, the ultimate Hollywood personification of the Special Forces as mythic warriors could be found in Sylvester Stallone's depiction of John Rambo. While the Rambo series relied on the traumatized veteran trope, his redemption would ultimately lay in his frontier warfare skills. And these skills were not acquired in the Boy Scouts, nor were they God-given. ${ }^{275}$ As Colonel Trautman declared in First Blood, "God didn't make Rambo. I made him.” Trautman's enumeration of Rambo's skills appeared to have been lifted directly from 1960s media coverage of the Green Berets. Rambo was an "expert in guerrilla warfare," a master of killing with guns, knives, or with his bare hands. He could "live off the land" and "eat things that would make a billy goat puke." 276 In director Ted Kotcheff"s 1982 film, Rambo descended a mountainous rock face, sewed up his own wounds, and hunted wild boar. Even the explosive arrows Rambo used in later films were straight out of early media articles on the Green Berets. ${ }^{277}$

\footnotetext{
${ }^{272}$ A similar phenomenon could be seen with regards to the U.S. Marines depicted in Stanley Kubrick's 1987 film Full Metal Jacket. For Cimino's comments on his film, see John M. Wilson, “'The Deer Hunter' Is a War Film That's Incited a War All of Its Own," Dayton Daily News, May 13, 1979.

${ }^{273}$ Monte Plott, "Berets Still Ready," Dayton Daily News, June 2, 1978.

274 “The Oscar Night: Vietnam Finally Is a Winner," San Francisco Examiner, April 10, 1979.

275 On the placement of such depictions within the Reagan era, see Jeffords, The Remasculinization of America, 127130. Later films in the Rambo series added a backstory that explained some of his skills through his ancestry.

${ }^{276}$ First Blood, directed by Ted Kotcheff, featuring Sylvester Stallone (Orion, 1982), 0:45:58 to 0:46:15.

${ }^{277}$ One newspaper article stated that "Fort Bragg's guerrillas" are experts with bows and arrows. The arrows can be fitted with a "dynamite cap" to explode gasoline dumps. See Bem Price, "Fort Bragg's Master Troublemakers," Raleigh News and Observer, June 21, 1959.
} 
The films also presented the fantasy that if these super soldiers had just been allowed to do their job, then the United States would not have "lost" the war in Vietnam. As Rambo told Trautman, "I did what I had to do to win. But somebody wouldn't let us win." ${ }^{278}$ Redemption thus fell within the purview of the Green Berets, for through Rambo, the war in Vietnam could be refought and this time, it could be won. In Rambo: First Blood Part II, Rambo not only defeated the North Vietnamese, but also the Soviets and his own country's bureaucrats to bring American POWs home: "Mission accomplished."279 Predator allowed for a similar fiction, though the Arnold Schwarzenegger flick featured Green Berets in Central America taking on an extraterrestrial. Still, the themes of government betrayal, of elite soldiers surviving through their mastery of frontier skills, and of using the enemy's own weapons against him were the same.

It is important to note, however, that the core themes within these 1980s action movies had long cultural roots. The Kennedy-era myth of the Green Berets as America's soldiers of democratic progress was compelling to many young men. The problem, though, was that these soldiers' idealism rarely survived the reality of the war they experienced in Vietnam. Thomas Perry, who spoke of "drawing closer to the truth behind the myth of Special Forces," had expected to be working with men who understood the "large scope of the war," who could "work successfully with a rifle squad or with a Montagnard village." ${ }^{280}$ But he was disheartened to encounter no one in Vietnam who fit the image he had been sold. Likewise, he had expected to be fighting die-hard communists, but instead realized, "we're here killing nationalists most of the time." ${ }^{281}$ Donald Duncan, a Green Beret turned anti-war activist, also went to Vietnam

\footnotetext{
${ }^{278}$ First Blood, 1:25:36 to 1:25:42.

${ }^{279}$ Rambo: First Blood Part II, directed by George P. Cosmatos, featuring Sylvester Stallone (TriStar, 1985), $1: 29: 50$ to $1: 30: 00$.

${ }^{280}$ Perry to wife, January 2 and 16, 1968, Perry Correspondence.

${ }^{281}$ Perry to wife, tape recording, May 9, 1968, Perry Correspondence.
} 
ideologically motivated, though his support for his government's cause soon faded. Duncan was "completely taken aback" by the contempt his fellow soldiers expressed toward the Vietnamese government, soldiers, and civilians. ${ }^{282}$ After all, these were the very people upon whose support the counterinsurgency effort depended. Like many of his veteran peers, Duncan became increasingly aware of the incongruity between the official stance of the U.S. military and the reality of the situation on the ground.

Even many of those young men who joined the Special Forces to experience combat as part of an elite group of soldiers were similarly disillusioned with the war. James McLeroy became "extremely demoralized" when he was expected to train and lead CIDG troops, whom he found to be "absolutely worthless." 283 He wanted to "get with some guys who were out to win the war and kill the enemy and take it to them." But after moving to a more combat-oriented posting, he only grew more "bitter and disillusioned" with the way the war was being waged. ${ }^{284}$ Reflecting on his service in Vietnam, McLeroy admitted that he would have been happier leading an elite infantry unit rather than indigenous troops. Duncan said he had observed many men like McLeroy in Vietnam, "self-styled John Waynes," who complained about being "forced to build schools and distribute food" when their "real job" should have been "killing Viet Cong." 285

That such aspiring soldiers as Perry and McLeroy, with dissimilar motivations for joining the Special Forces, could be inspired by the same myth is a testament to the power of the popular

\footnotetext{
${ }^{282}$ Duncan, The New Legions, 224.

${ }^{283}$ McLeroy, interview, 10. McLeroy was at Kham Duc when it was overrun by the North Vietnamese Army on May 12, 1968. He described his CIDG troops throwing down their weapons and deserting, which contributed to his strong negative assessment of the CIDG forces. McLeroy coauthored a book on the attack, see James D. McLeroy and Gregory W. Sanders, Bait: The Battle of Kham Duc (Havertown, PA: Casemate, 2019). This battle is the one in which Thomas Perry went missing and was later presumed dead.

${ }^{284}$ McLeroy, interview, 11, 32.

${ }^{285}$ Don Duncan, Ephemera, Ramparts 4, no. 10 (February 1966): 66.
} 
folklore that has surrounded the Green Berets since their founding. It is a problem that persists to this day. In her 1997 study on the Special Forces, anthropologist Anna Simons remarked upon the divide that existed within each team between those who preferred pure combat mission and those who took to heart the demands of more politically based missions such as training foreign fighters. ${ }^{286}$ Other scholars have made similar arguments. For instance, political scientist Michael McClintock maintains that the "fiction that Special Forces can be both Rambo-style warriors and sensitive development workers who can diagnose and defuse internal unrest through civic action has yet to be dispelled." ${ }^{287}$ But it is this duality that gives the myth its staying power and led to its recrudescence in the Global War on Terror.

In 2008, the Department of Defense released an hour-long film, Why We Fight Now: The Global War on Terror. ${ }^{288}$ While the film touted the capabilities of the Special Forces as the premier unconventional warriors of the twenty-first century, at heart, it merely parroted Kennedy-era stereotypes. Themes of the Special Forces as warrior diplomats, the importance of winning hearts and minds, and protecting American shores by taking the fight to the enemy ran throughout the film. In this way, the myth is kept alive for a new generation, demonstrating that what was past is still present. For though the enemy may have changed, the heroic warrior-savior still wears a green beret.

Myths reflect deeply held societal beliefs, which is precisely what makes them so powerful. For this reason, they can also be incredibly dangerous. The warrior mystique of the Green Berets in the Vietnam era not only provided the American public with a "hero" figure, it

\footnotetext{
286 Though her study was published in 1997, the same inherent conflict exists within the Special Forces today in the Global War on Terror. Simons, The Company They Keep, 52.

${ }^{287}$ McClintock, Instruments of Statecraft, 246.

${ }^{288}$ Why We Fight Now: The Global War on Terror, produced by Frank Capra, Jr., directed by Mark Benjamin (Department of Defense, 2008). The film, unsurprisingly, featured Sadler's ballad.
} 
also gave them a way by which to imagine that victory in a largely unconventional war was possible. That myth survives to this day. A monument to the horse soldiers of $5^{\text {th }}$ Special Forces Group, who rode to "victory" in Afghanistan, stands on the grounds of Liberty Park, the former site of the World Trade Center. However, despite billions of dollars and nearly twenty years of fighting, the United States has not defeated the Taliban. The myth survives in popular culture as well. Quentin Tarantino was criticized when his film Once Upon a Time in Hollywood portrayed Bruce Lee losing a fight to the protagonist stuntman, Cliff. Tarantino dismissed his critics by explaining that Cliff was a Green Beret, a warrior, who was used to killing men in unarmed combat. For sixty years, then, the mythology has served as a tool to suit the needs of politicians, the media, the military, and the larger American public.

Continuing to lionize the Special Forces has consequences, however. One of which is that it enables continued, robust, and global interventionism. Civilian and military leaders rely on Special Forces teams to solve thorny foreign policy problems with minimal public debate or attention. The American public, meanwhile, acquiesces because it understands the versatility and expertise of these warrior diplomats. But even the best-trained soldiers are not social scientists and allowing the Army to be a vehicle of "progress" in the Global South assumes a degree of sophistication and cultural awareness that is belied by the historical data.

Deconstructing the mythology of the Green Berets as "gunslinging schoolteachers" reveals the faulty assumptions that undergird American foreign policy. After all, the notion that Special Forces soldiers can enter a foreign country and truly understand the needs of the local populace-and then help transform that society-is the embodiment of cultural superiority. It is hubris to make foreign policy decisions on deploying armed forces abroad when those decisions are based on an uncritical faith in the superiority of "elite" western soldiers. Such assumptions 
blind policymakers to alternative options that might be better suited for local conditions and beliefs. Whether or not Green Berets can assist in nation building is a different question than asking whether they should. American modernization ideals of democracy, capitalism, and social progress are not going to be the one-size-fits-all solution to the world's problems. Pretending otherwise, and presuming that our soldiers, even our most elite, can remake the world in America's image is a dangerous conceit. The Green Berets were never everything that their myth promised but that is only because the myth of American exceptionalism was, and continues to be, so appealing. We cannot teach other nations the best way to govern, the optimal manner in which to build their markets, or to grow their crops. These are local decisions and they have local ramifications that American military personnel can never fully comprehend. The mistakes we, as a nation, made in Vietnam have been repeated in Afghanistan and Iraq. It is time to look past the myth and ask ourselves: are our elite warriors gunslingers or are they diplomats? Because they cannot be both. 


\title{
Bibliography
}

\section{PRIMARY SOURCES}

\section{Books:}

Derrig, Peter. The Pride of the Green Berets. New York: Paperback Library, 1966.

Duncan, Donald. The New Legions. New York: Random House, 1967.

Ford, Daniel. Incident at Muc Wa. New York: DoubleDay, 1967.

Lederer, William J. and Eugene Burdick. The Ugly American. New York: W. W. Norton \& Company, 1958.

Michaels, Rand. Women of the Green Berets. New York: Lancer Books, 1967.

McCroskey, Jacob. Operation Axe-Handle. New York: Lancer Books, 1967.

Moore, Robin. The Green Berets. New York: Crown Publishers, 1965.

Moore, Robin. The Green Berets. Rev. ed. New York: Skyhorse, 2015.

Morris, Jim. War Story. Boulder, CO: Paladin, 1979.

Sadler, Barry and Tom Mahoney. I'm a Lucky One. New York: Macmillan, 1967.

Siemer, Bill. Skeletons to Find: A Vietnam Diary. Self-published, 1st Books Library, 2003.

\section{Periodicals, Newspapers, Comic Books:}

\author{
American Cinematographer \\ Arizona Republic \\ Army \\ Army Times \\ Army Attack \\ Atlanta Constitution \\ Baltimore Sun \\ Billboard \\ Boston Globe \\ Charlotte News \\ Chicago Tribune
}


Clarion-Ledger

Clarksville Leaf-Chronicle

Dayton Daily News

Escanaba Daily Press

Esquire

Fayetteville Observer

Fight the Enemy

Fightin' Army

Florida Today

Fort Lauderdale News

Fort Worth Star-Telegram

Green Beret

Harper's

Honolulu Advertiser

Jungle War Stories

Knoxville News-Sentinel

Lansing State Journal

Lawton Constitution

Life

Look

Los Angeles Times

Male

Miami Herald

Minneapolis Star

Napa Valley Register

National Geographic

New York Times

Our Fighting Forces

Petaluma Argus-Courier

Philadelphia Daily News

Pittsburg Press

Playboy

Popular Mechanics

Raleigh News and Observer

Raleigh Register

Ramparts

Rio Grande Sun

Robesonian

San Antonio Express

San Francisco Examiner

Saturday Evening Post

Sears Catalog

Spokane Chronicle

Spokesman-Review

St. Louis Post-Dispatch

Super Green Beret 
Sydney Morning Herald

Tennessean

Time

Veritas

Wall Street Journal

War Heroes

Washington Post

Winona Daily News

\section{Interviews and Letters:}

Brady, Martin. Interview with Richard Burks Verrone. June 25, July 9, and August 20, 2003. Oral History Project, Vietnam Center and Sam Johnson Vietnam Archive, Texas Tech University.

Gardner, Norm. Interview with Stephen Maxner. March 14, 2001. Oral History Project, Vietnam Center and Sam Johnson Vietnam Archive, Texas Tech University.

Gritzmaker, Aaron. Interview with Jason Stewart. September 29, 2008. Oral History Project, Vietnam Center and Sam Johnson Vietnam Archive, Texas Tech University.

Kreger, Robert. Interview with Laura Calkins. October 28, November 11, December 9, 2005 and February 9, 14, 16, 21, March 7, 28, 2006. Oral History Project, Vietnam Center and Sam Johnson Vietnam Archive, Texas Tech University.

McLeroy, James. Interview with Stephen Maxner. September 18 and October 3, 2000. Oral History Project, Vietnam Center and Sam Johnson Vietnam Archive, Texas Tech University.

Perry, Thomas Hepburn. Thomas Hepburn Perry Vietnam War Correspondence (2018-093-wc). Center for American War Letters, Chapman University, CA.

Shippen, Robert. Interview with Richard B. Verrone. May 25-26, August 7, 10-11, 14, September 11, 21-22, and October 6, 2006. Oral History Project, Vietnam Center and Sam Johnson Vietnam Archive, Texas Tech University.

Sylvester, Arthur. Interview with Lawrence H. Suid. December 23, 1974. JFKOH-AUS-02. John F. Kennedy Presidential Library and Museum.

\section{Speeches:}

Kennedy, John F. “The New Frontier Acceptance Speech.” July 15, 1960. JFKCAMP1960-1032027-p0001. John F. Kennedy Presidential Library and Museum. 
Kennedy, John F. "Inaugural Address.” January 20, 1961. USG-17. John F. Kennedy Presidential Library and Museum.

Kennedy, John F. "Special Message to Congress on Urgent National Needs.” May 25, 1961. JFKPOF-034-030. John F. Kennedy Presidential Library and Museum.

\section{Songs, Movies, and Television Shows:}

First Blood. Directed by Ted Kotcheff, featuring Sylvester Stallone. Orion, 1982.

Green Berets, The. Directed by John Wayne and Ray Kellogg, featuring John Wayne. Batjac, 1968.

Seven Days in May. Directed by John Frankenheimer, screen play by Rod Serling. Paramount, 1964.

Surfside 6. Season 2, episode 24, "The Green Beret." Directed by Paul Landres, featuring Lee Patterson. Aired March 5, 1962, on ABC (Warner Brothers Television).

"The Ballad of the Green Berets." Lyrics by Barry Sadler and Robin Moore, performed by Barry Sadler. Recorded December 1965. RCA Victor.

"The Story of the Green Beret." GI Joe: Stories of Patriotic Americans. Hanna-Barbera Records, 1966. Catalogue number HL 2057.

Twilight Zone. Season 5, episode 1, "In Praise of Pip." Directed by Joseph M. Newman, written by Rod Serling. Aired September 27, 1963, on CBS (CBS Productions).

Why We Fight Now: The Global War on Terror. Produced by Frank Capra, Jr., directed by Mark Benjamin. Department of Defense, 2008.

\section{Other Government Publications:}

Department of the Army, Army Concept Team in Vietnam. Employment of a Special Forces Group. April 20, 1966. https://apps.dtic.mil/dtic/tr/fulltext/u2/374659.pdf.

Department of the Army, Office of the Director of Strategic Plans and Policy, Special Warfare Division. Counter Insurgency Operations: A Handbook for the Suppression of Communist Guerrilla/Terrorist Operations. December 1, 1960. Item 2620125001, Ronald Rodeck Collection, Vietnam Center and Sam Johnson Vietnam Archive, Texas Tech University.

Kelly, Francis J. U.S. Army Special Forces, 1961-1971. 1973. Reprint, Washington, DC: US Government Printing Office, 2004. 
Special Warfare, U.S. Army. Department of the Army. US Government Printing Office, 1962.

\section{SECONDARY SOURCES}

\section{Books:}

Adair, Gilbert. Hollywood's Vietnam: From The Green Berets to Apocalypse Now. New York: Proteus, 1981.

Adams, Thomas K. US Special Operations Forces in Action: The Challenge of Unconventional Warfare. 1998. Reprint, Portland, OR: Frank Cass, 2001.

Alsop, Stewart and Thomas Braden. Sub Rosa: The OSS and American Espionage. 1946.

Reprint, New York: Harcourt, Brace \& World, 1964.

Bacevich, Andrew J. The New American Militarism: How Americans Are Seduced by War. New York: Oxford University Press, 2005.

Bank, Aaron. From OSS to Green Berets: The Birth of Special Forces. Novato, CA: Presidio Press, 1986.

Beaumont, Roger A. Military Elites. New York: Bobbs-Merrill Company, 1974.

Betts, Richard K. Soldiers, Statesmen, and Cold War Crises. Cambridge: Harvard University Press, 1977.

Birtle, Andrew J. U.S. Army Counterinsurgency and Contingency Operations Doctrine, 19421976. Washington, DC: US Government Printing Office, 2006.

Blaufarb, Douglas S. The Counterinsurgency Era: U.S. Doctrine and Performance, 1950 to the Present. New York: Macmillan, 1977.

Bourne, Peter G. Men, Stress, and Vietnam. Boston: Little, Brown and Company, 1970.

Cable, Larry E. Conflict of Myths: The Development of American Counterinsurgency Doctrine and the Vietnam War. New York: New York University Press, 1986.

Chambers, John Whiteclay, II. OSS Training in the National Parks and Service Abroad in World War II. Washington, DC: US National Park Service, 2008.

https://www.nps.gov/parkhistory/online_books/oss/.

Cohen, Eliot A. Commandos and Politicians: Elite Military Units in Modern Democracies. Cambridge, MA: Center for International Affairs, 1978. 
Engelhardt, Tom. The End of Victory Culture: Cold War America and the Disillusioning of a Generation. Amherst, MA: University of Massachusetts Press, 1995.

Gibson, James William. Warrior Dreams: Violence and Manhood in Post-Vietnam America. New York: Hill and Wang, 1994.

Hallin, Daniel C. The "Uncensored War:" The Media and Vietnam. Los Angeles: University of California Press, 1989.

Hellmann, John. American Myth and the Legacy of Vietnam. New York: Columbia University Press, 1986.

Hilsman, Roger. To Move a Nation: The Politics of Foreign Policy in the Administration of John F. Kennedy. Garden City, NY: Doubleday, 1967.

Huebner, Andrew J. The Warrior Image: Soldiers in American Culture from the Second World War to the Vietnam Era. Chapel Hill: University of North Carolina Press, 2008.

Jeffords, Susan. The Remasculinization of America: Gender and the Vietnam War. Bloomington: Indiana University Press, 1989.

Jewett, Robert and John Shelton Lawrence. The American Monomyth. Garden City, NY: Anchor Press/Doubleday, 1977.

Latham, Michael. Modernization as Ideology: American Social Science and "Nation Building" in the Kennedy Era. Chapel Hill: University of North Carolina Press, 2000.

Leepson, Marc. Ballad of the Green Beret: The Life and Wars of Staff Sergeant Barry Sadler. Guilford, CT: Stackpole Books, 2017.

Lepore, Jill. The Name of War: King Philip's War and the Origins of American Identity. New York: Alfred A. Knopf, 1998.

Mantell, David Mark. True Americanism: Green Berets and War Resisters, A Study of Commitment. New York: Teachers College Press, 1974.

McClintock, Michael. Instruments of Statecraft: U.S. Guerrilla Warfare, Counterinsurgency, and Counterterrorism, 1940-1990. New York: Pantheon Books, 1992.

Milam, Ron, ed. The Vietnam War in Popular Culture: The Influence of America's Most Controversial War on Everyday Life, Vol. 1, During the War. Santa Barbara: Praeger, 2017.

Milam, Ron, ed. The Vietnam War in Popular Culture: The Influence of America's Most Controversial War on Everyday Life, Vol. 2, After the War. Santa Barbara: Praeger, 2017. 
Mossman, B.C. and M. W. Stark. The Last Salute: Civil and Military Funerals, 1921-1969. Washington, DC: US Government Printing Office, 1991.

Mundey, Lisa M. American Militarism and Anti-Militarism in Popular Media, 1945-1970. Jefferson, NC: McFarland \& Company, 2012.

Paddock, Alfred H., Jr. U.S. Army Special Warfare: Its Origins. Revised Edition. Lawrence, KS: University of Kansas Press, 2002.

Roosevelt, Kermit. War Report of the OSS (Office of Strategic Services). New York: Walker and Company, 1976.

Schlesinger, Arthur M., Jr. A Thousand Days: John F. Kennedy in the White House. 1965. Reprint, New York: Houghton Mifflin, 2002.

Sidey, Hugh. John F. Kennedy, President. New York: Atheneum, 1964.

Simons, Anna. The Company They Keep: Life Inside the U.S. Army Special Forces. New York: Free Press, 1997.

Simpson, Charles M., III. Inside the Green Berets: The First Thirty Years, A History of the U.S. Army Special Forces. Novato, CA: Presidio Press, 1983.

Slotkin, Richard. Gunfighter Nation: The Myth of the Frontier in Twentieth-Century America. Norman, OK: University of Oklahoma Press, 1998.

Stanton, Shelby L. Green Berets at War: U.S. Army Special Forces in Southeast Asia, 19561975. New York: Ivy Books, 1985.

Stur, Heather Marie. Beyond Combat: Women and Gender in the Vietnam War Era. New York: Cambridge University Press, 2011.

Suid, Lawrence H. Guts and Glory: The Making of the American Military Image in Film. Lexington, KY: University Press of Kentucky, 2002.

Taylor, Maxwell D. The Uncertain Trumpet. New York: Harper \& Brothers, 1960.

Thayer, Charles W. Guerrilla. New York: Signet Books, 1965.

Walton, Richard J. Cold War and Counterrevolution: The Foreign Policy of John F. Kennedy. New York: Viking Press, 1972.

Watts, Steven. JFK and the Masculine Mystique: Sex and Power on the New Frontier. New York: St. Martin's Press, 2016. 
Wilensky, Robert J. Military Medicine to Win Hearts and Minds: Aid to Civilians in the Vietnam War. Lubbock, TX: Texas Tech University Press, 2004.

Wright, Bradford W. Comic Book Nation: The Transformation of Youth Culture in America. Baltimore: Johns Hopkins University Press, 2001.

\section{Articles:}

Cockerham, William C. "Green Berets and the Symbolic Meaning of Heroism." Urban Life 8, no. 1 (April 1979): 94-113.

Cowans, Jon. "A Deepening Disbelief: The American Movie Hero in Vietnam, 1958-1968." Journal of American-East Asian Relations 17, no. 4, THEME ISSUE: Film Across the Pacific: Projections, Screens, and Mirrors - Part One (2010): 324-351.

Daddis, Gregory A. "Eating Soup with a Spoon: The U.S. Army as a 'Learning Organization' in the Vietnam War.” Journal of Military History 77 (January 2013): 229-254.

Gustainis, J. Justin. "John F. Kennedy and the Green Berets: The Rhetorical Use of the Hero Myth," Communication Studies 40, no. 1 (1989): 41-53.

Hill, Nathan C. “Sowing Dragon's Teeth: OSS Operational Groups of World War II.” Military Review (July-August 2013): 31-37.

Koenig, Cindy. "The Story of the Green Berets: An Account of the American Monomyth." Journal of the Northwest Communication Association 32 (Summer 2003): 59-77.

Rushing, Janice Hocker. "Mythic Evolution of 'The New Frontier' in Mass Mediated Rhetoric." Critical Studies in Mass Communication 3, no. 3 (September 1986): 265-296.

Slotkin, Richard. "Gunfighters and Green Berets: ‘The Magnificent Seven' and the Myth of Counter-Insurgency." Radical History Review, no. 44 (Spring 1989): 65-90.

Spark, Alasdair. "The Soldier at the Heart of the War: The Myth of the Green Beret in the Popular Culture of the Vietnam Era." Journal of American Studies 18, no. 1 (April 1984): 29-48.

Strassfeld, Robert N. "Vietnam War on Trial: The Court Martial of Dr. Howard B. Levy." Wisconsin Law Review 1994, no. 4 (1994): 839-964.

Suid, Lawrence. "Hollywood and Vietnam." Film Comment 15, no. 5 (September-October 1979): 20-25.

Willoquet-Maricondi, Paula. "Full-Metal-Jacketing, or Masculinity in the Making." Cinema Journal 33, no. 2 (Winter 1994): 5-21. 